\title{
7. CARBONATE CEMENTATION OF GRANULAR AND FRACTURE POROSITY: IMPLICATIONS FOR THE CENOZOIC HYDROLOGIC DEVELOPMENT OF THE PERU CONTINENTAL MARGIN ${ }^{1}$
}

\author{
Todd M. Thornburg ${ }^{2}$ and Erwin Suess ${ }^{3}$
}

\begin{abstract}
The evolution of pore fluids migrating through the forearc basins, continental massif, and accretionary prism of the Peru margin is recorded in the sequence of carbonate cements filling intergranular and fracture porosities. Petrographic, mineralogic, and isotopic analyses were obtained from cemented clastic sediments and tectonic breccias recovered during Leg 112 drilling. Microbial decomposition of the organic-rich upwelling facies occurs during early marine diagenesis, initially by sulfate-reduction mechanisms in the shallow subsurface, succeeded by carbonate reduction at depth. Microcrystalline, authigenic cements formed in the sulfate-reduction zone are ${ }^{13} \mathrm{C}$-depleted (to $-20.1 \%$ PDB), and those formed in the carbonate-reduction zone are ${ }^{13} \mathrm{C}$-enriched (to $+19.0 \%$ PDB). Calcium-rich dolomites and near-stoichiometric dolomites having uniformly heavy $\delta^{18} \mathrm{O}$ values $(+2.7$ to $+6.6 \%$ PDB) are typical organic decomposition products. Quaternary marine dolomites from continental-shelf environments exhibit the strongest sulfate-reduction signatures, suggesting that Pleistocene sea-level fluctuations created a more oxygenated water column, caused periodic winnowing of the sediment floor, and expanded the subsurface penetration of marine sulfate.

We have tentatively identified four exotic cement types precipitated from advected fluids and derived from the following diagenetic environments: (1) meteoric recharge, (2) basalt alteration, (3) seafloor venting and (4) hypersaline concentration. Coarsely crystalline, low-magnesium (Lo-Mg) calcite cements having pendant and blocky-spar morphologies, extremely negative $\delta^{18} \mathrm{O}$ values (to $-7.5 \%$ PDB), and intermediate $\delta^{13} \mathrm{C}$ values $(-0.4 \%$ to $+4.6 \%$ PDB) are found in shallow-marine Eocene strata. These cements are evidently products of meteoric diagenesis following subaerial emergence during late Eocene orogenic movements, although the strata have since subsided to greater than $4,000 \mathrm{~m}$ below sea level. Lo-Mg calcite cements filling scaly fabrics in the late Miocene accretionary prism sediments are apparently derived from fluids having lowered magnesium/calcium $(\mathrm{Mg} / \mathrm{Ca})$ and ${ }^{18} \mathrm{O} /{ }^{16} \mathrm{O}$ ratios; such fluids may have reacted with the subducting oceanic crust and ascended through the forearc along shallow-dipping thrust faults. Micritic, high-magnesium ( $\mathrm{Hi}-\mathrm{Mg}$ ) calcite cements having extremely depleted $\delta^{13} \mathrm{C}$ values (to $-37.3 \%$ PDB), and a benthic fauna of giant clams (Calyptogena sp.) supported by a symbiotic, chemoautotrophic metabolism, provide evidence for venting of methane-charged waters at the seafloor. Enriched $\delta^{18} \mathrm{O}$ values (to $+6.6 \%$ PDB) in micritic dolomites from the continental shelf may be derived from hypersaline fluids that were concentrated in restricted lagoons behind an outer-shelf basement ridge, reactivated during late Miocene orogenesis.
\end{abstract}

\section{INTRODUCTION}

The general understanding of hydrogeologic processes in convergent margin settings is in its infancy, but is subject to a major research effort by the scientific community (COSOD II, 1988; Cloos, 1984; Bray and Karig, 1985; Kulm et al., 1986; Carson and Berglund, 1987; Boulegue et al., 1987; Moore et al., 1987; Han and Suess, 1988; Vrolijk, 1987; Shi et al., 1989). The cement stratigraphy of carbonate precipitates provides historical documentation of fluid compositions no longer present in subsurface porous media. Pore fluids advected from deeply buried, diagenetic and tectonic environments may be preserved in the cementation record, providing valuable clues about the migration and chemical evolution of fluids that originate beyond our range of sampling capability. Time, space, and depth-dependent variations in the compositions of carbonate cements collected during Leg 112 drilling may elucidate the influences of subduction tectonics, eustacy, climate, and oceanography on the Cenozoic hydrogeology of the central Peru forearc.

\footnotetext{
${ }^{1}$ Suess, E., von Huene, R., et al., 1990. Proc. ODP., Sci. Results, 112: College Station, TX (Ocean Drilling Program). 5503.

2 College of Oceanography, Oregon State University, Corvallis, OR 97331-

${ }^{3}$ GEOMAR Research Center for Marine Geosciences, Wischhofstrasse 1-3, D-2300 Kiel, Federal Republic of Germany.
}

Petrographic, mineralogic, and stable carbon and oxygen isotopic analyses of carbonate cements from Sites 679 through 688 (Fig. 1) and site-survey dredge samples (Fig. 2) are presented, and preliminary interpretations of the sources and migration pathways of subsurface fluids in the Andean forearc are discussed. Two end-member cement types may be considered-authigenic and exotic-with continuous gradation and hybridization between these two idealized, diagenetic products. Authigenic carbonate cements form in contact with local fluids trapped in porous, unconsolidated muds, where solute movement is dominated by diffusion processes over short distances. Extensively studied diagenetic carbonates recovered from the Peru margin and other organic-rich marine basins appear to be primarily of authigenic type (Irwin et'al., 1977; Pisciotto and Mahoney, 1981; Kelts and McKenzie, 1982; Kulm et al., 1984; Baker and Burns, 1985; Suess et al., 1987). In contrast, exotic cements are precipitated along permeable transport pathways by fluids that have advected over much longer distances through forearc basin strata and, potentially, the crystalline basement of the continental massif or subducting oceanic crust. Hydrogeologic information is thus preserved in the cementation history of lithologies containing primary or secondary fabrics of high permeabilitydetrital or biogenic sands with depositional interparticle porosity (bedding-parallel permeability) and brecciated carbonates with post-depositional fracture porosity (across-bedding permeability). Exotic cement sequences will likely document 

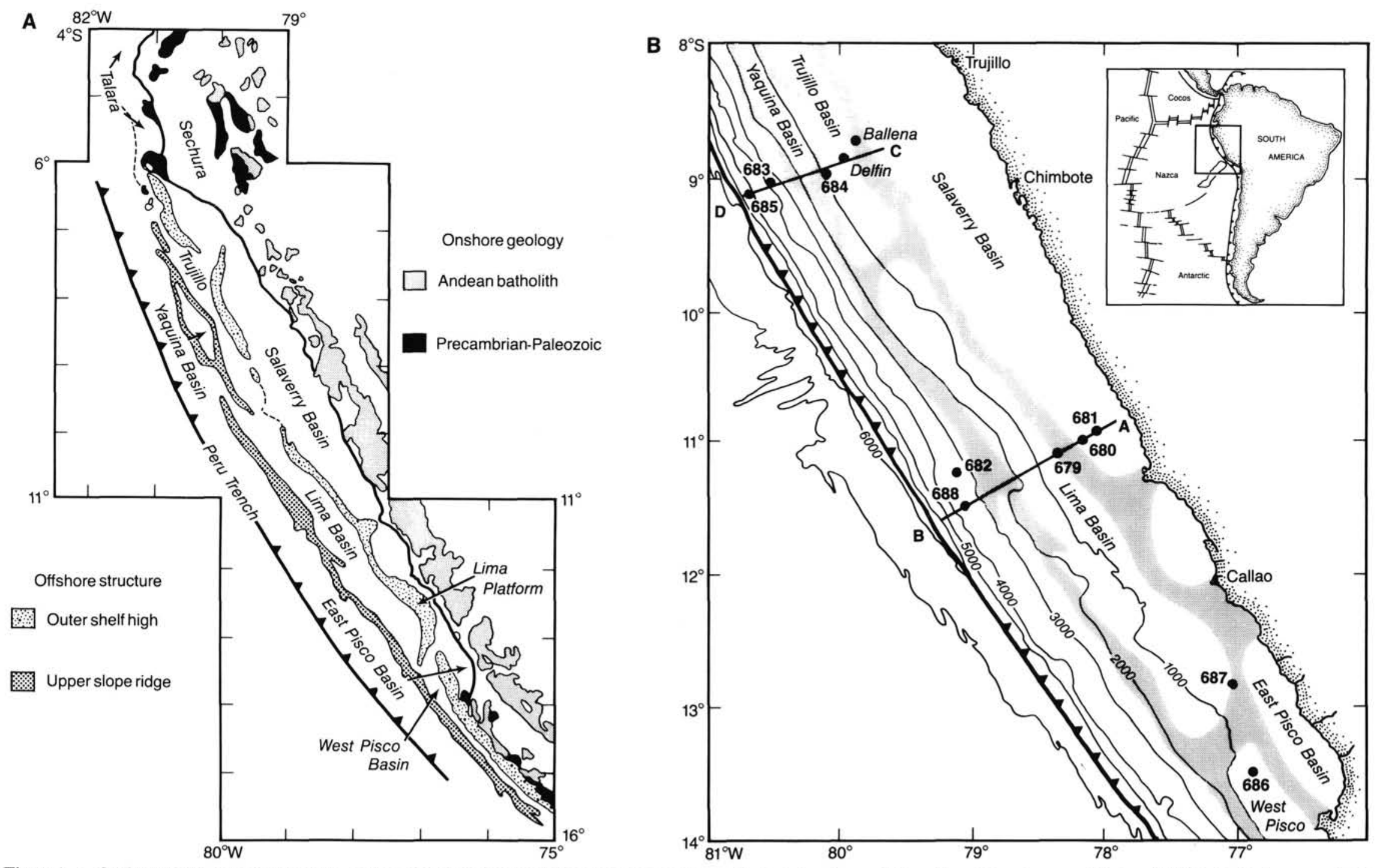

Figure 1. A. Onshore basement massifs of the Andean and Coastal Cordilleras and subparallel, geanticlinal structures offshore (from Thornburg and Kulm, 1981). B. Drill sites occupied by ODP Leg 112 (Sites 679-688) and the petroleum industry (Delfin and Ballena wells). Offshore structural ridges are stippled. Insert depicts the regional plate-tectonic setting at the convergent boundary between the Nazca and South American plates. 

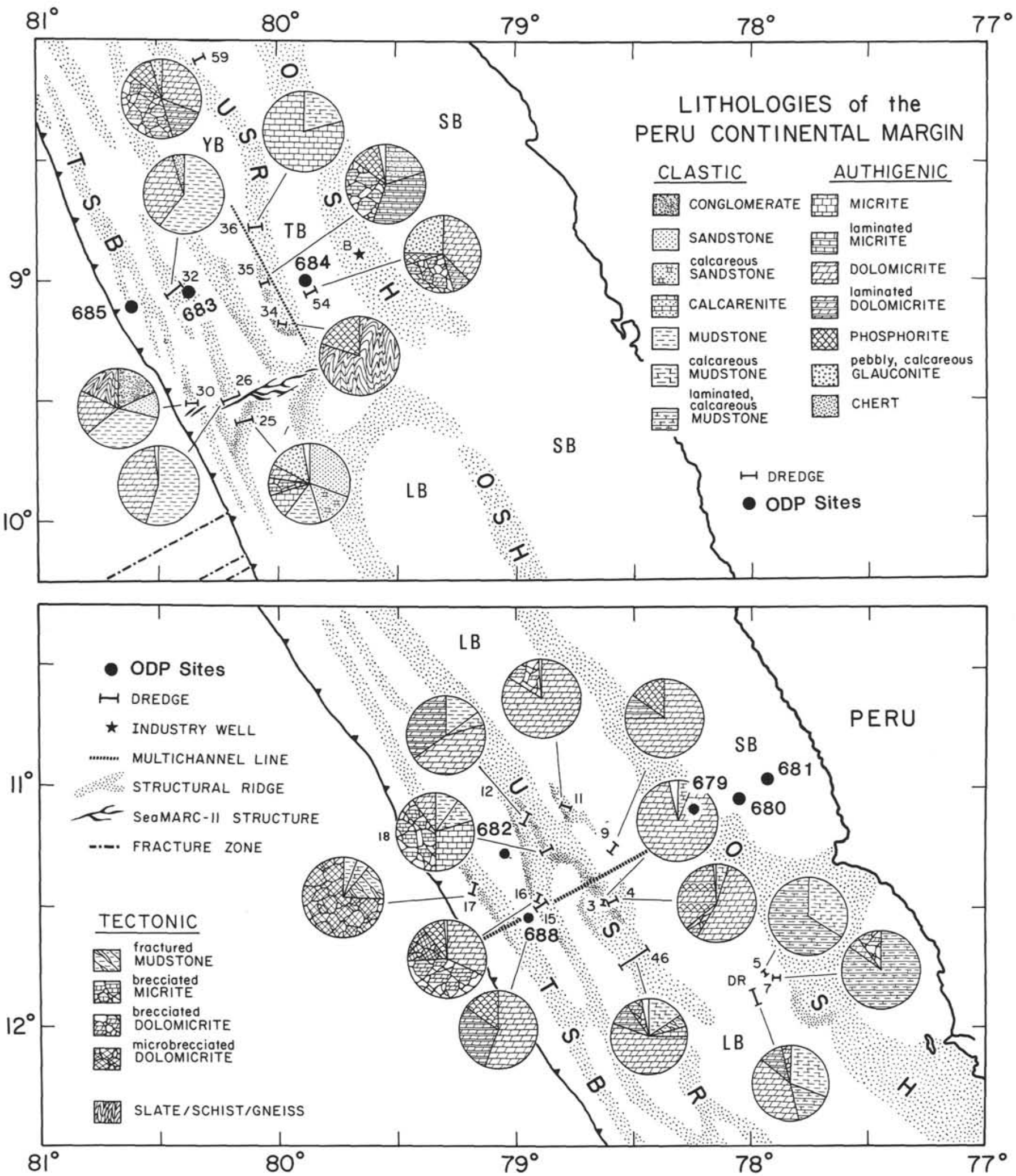

Figure 2. Dredges obtained during the site-survey program (Moana Wave, April 1985) and a previous cruise (Wecoma, June 1977); Leg 112 drill sites are also located. Pie diagrams indicate volume-percentages of major lithologies, although the actual volumes recovered varied considerably and generally decreased with water depth. $\mathrm{SB}=$ Salaverry Basin; $\mathrm{TB}=$ Trujillo Basin; $\mathrm{LB}=\mathrm{Lima}$ Basin; YB $=\mathrm{Yaquina} \mathrm{Basin} ; \mathrm{OSH}=$ Outer-Shelf High; USR = Upper-Slope Ridge; TSB = Trench-Slope Break. See Kulm et al. (1988) for complete descriptions of dredged lithologies. 
fluid compositions that span longer time intervals and extend to greater burial depths because compaction and lithification eventually inhibit authigenic precipitation mechanisms.

\section{STRUCTURAL AND STRATIGRAPHIC SETTING}

The Cenozoic basins of the Peru continental margin are delimited by horstlike basement elements trending subparallel to the Andean structural grain (Travis et al., 1976; Thornburg and Kulm, 1981; Thornburg, 1985; Ballesteros et al., 1988) (Figs. 1, 2). Coastal basins crop out onshore between the Coast Range and the Andean Cordillera in northwest Peru (Sechura Basin) and southwest Peru (Pisco Basin), but in central Peru the sea has transgressed to the foothills of the Andes, forming a broad continental shelf underlain by the correlative Salaverry Basin. The submarine extension of the Coast Range forms an outer-shelf structural high composed of pre-Andean, continental basement rocks (Outer-Shelf High or "OSH" of Figs. 1 and 2; Thornburg and Kulm, 1981). A second, subparallel structural ridge lies seaward (Upper-Slope Ridge or "USR"), and between these two basement elements are cradled the upper-slope forearc basins-the Trujillo Basin of north-central Peru and the Lima Basin of south-central Peru. In a midslope position, the Yaquina Basin is perched on a foundered, intensely fractured continental plateau. Patchy, elongate, lower-slope basins are ponded behind the crest of a stunted accretionary complex (Trench-Slope Break or "TSB") at the leading edge of the continental block (Hussong et al., 1976; Thornburg, 1985; von Huene and Miller, 1988; Moore and Taylor, 1988).

Marine sedimentation in the offshore basins of central Peru generally began in Eocene time, following emergent conditions in the early Tertiary when the Coastal Batholith was emplaced and a basal unconformity was scoured into the continental, metamorphic basement and Mesozoic volcaniclastic strata (Thornburg et al., 1985 and references therein). An unconformity at the top of the middle Eocene section has regional significance along the central Peru forearc, and sediments from much of late Eocene and Oligocene time are not preserved. This event is present in all drill sites on the mid-to-lower continental slope that penetrated Eocene strata (Sites 682, 683, and 688; Fig. 1) and in an industry borehole on the upper continental slope (Delfin well, Fig. 2A). A regional unconformity had also developed near the close of the middle Miocene, but its precise timing and duration are variable (Sites 679, 682, 683, 684, and 688). Generally, the stratigraphic break encompasses several million years within the interval of 5 to $11 \mathrm{Ma}$. The Pliocene/Quaternary boundary is also unconformable in many of the shallow sites (Sites 679, 680, 681, and $684)$. The unconformities encountered in the offshore boreholes correlate well with periods of orogenesis, emergence, and continental erosion onshore (Noble et al., 1979; McKee and Noble, 1982; von Huene, Suess, et al., 1988).

The Lima Basin of south-central Peru and the Trujillo/ Yaquina basins of north-central Peru have undergone divergent tectonic and stratigraphic histories during the Cenozoic, although they occupy correlative structural positions on the mid-to-upper continental slope (Figs. 1, 2; Thornburg, 1985; Hussong et al., 1988; Ballesteros et al., 1988). Expanded Eocene and lower-to-middle Miocene sections in the Trujillo Basin are reduced or absent in the Lima Basin, either because the Trujillo Basin received more sediments during these times, or the Lima Basin strata were more effectively stripped during subsequent orogenic movements. Since late Miocene time, however, the Trujillo Basin has persisted as a broad, stable platform, bypassing sediment to downslope depositional sites, while the Lima Basin has undergone rapid subsidence ( 275 to $500 \mathrm{~m} / \mathrm{m} . \mathrm{y}$.) and hence received high rates of sediment influx
(Kulm et al., 1981, 1984). This along-strike dichotomy in the evolution of the central Peru margin has caused contrasting sedimentary facies to develop in the forearc basins, as well as contrasting pathways of marine diagenesis, yielding authigenic carbonate cements with distinctive chemical and isotopic signatures (Kulm et al., 1984; Suess et al., 1987).

\section{SAMPLES}

Brecciated carbonates and carbonate-cemented sandstones were collected from all Leg 112 drill sites, positioned in water depths ranging from 150 to $3800 \mathrm{~m}$, with ages ranging from the Eocene to the Quaternary (Fig. 1). Homogeneous, aphanitic carbonates were also sampled at periodic stratigraphic intervals to provide a control group of authigenic cements formed during the in-situ marine diagenesis of upwelling facies on the Peru shelf and slope. The regional coverage is augmented by dredge samples collected during the Leg 112 site-survey program and previous cruises (Fig. 2; Kulm et al., 1988).

\section{Carbonate-Cemented Sands}

Coarse-grained sedimentary facies associated with highenergy, shallow-marine environments and regional unconformities are variably cemented by carbonate minerals, and exhibit a high potential for bedding-parallel channeling and lateral advection of migrating pore fluids. Sands and gravels having continental-shelf affinities were recovered in Eocene strata of Sites 682 and 688 , although these deposits are now situated more than $4000 \mathrm{~m}$ below sea level (Fig. 1). To the north, coarse clastic sediments of Dredges 25 and 30, in water depths greater than $3800 \mathrm{~m}$, presumably correlate with this shallow-water Eocene facies at the base of the Cenozoic marine record (Fig. 2A; Kulm et al., 1988).

Throughout Cenozoic time, the central Peru margin experienced a history of prolonged subsidence punctuated by brief episodes of orogenic uplift (von Huene, Suess, et al., 1988). Coarse clastic sediments are associated with the regional unconformities and potential emergence surfaces that were created during Eocene/Oligocene and late Miocene time, and sometimes form the base of upward-fining sequences (Sites 679, 682, 684, and 688). Coarse-grained Pliocene-Quaternary deposits have been best developed on the modern continental shelf, where eustatic regressions in sea level caused a seaward migration of the high-energy littoral zone during glacial periods (Sites 680,681, 684, and 687).

\section{Carbonate Breccias}

Tectonic breccias displaying one or more generations of fracturing, with subsequent cementation of fracture porosity, provide avenues of enhanced permeability at high angles to bedding and efficient vertical conduction of pore fluids. The random-to-subparallel fabric of the breccias ranges from tightly interlocking blocks in clast support to floating blocks suspended in a slurrylike matrix of carbonate cement (Fig. 3A), similar to breccia fabrics described by Roehl (1981) and Redwine (1981) from the Monterey Formation of California. Such fabrics probably formed by catastrophic mechanisms involving rock dilation, pore-fluid expulsion, and hydraulic fracturing associated with tectonic strain or deep-seated gravitational failure.

Similar breccia fabrics were encountered in consolidated muds during Leg 112 drilling, although tectonic brecciation could rarely be unequivocally separated from drilling-induced deformation. Examples of primary breccia fabrics may possibly be found in upper Oligocene strata of Site 682 , where mudstone blocks and sedimented fractures are clearly truncated by well-defined boundaries of drilling biscuits (Fig. 3B). The fracture-filling sediment is paler, more compact, and 


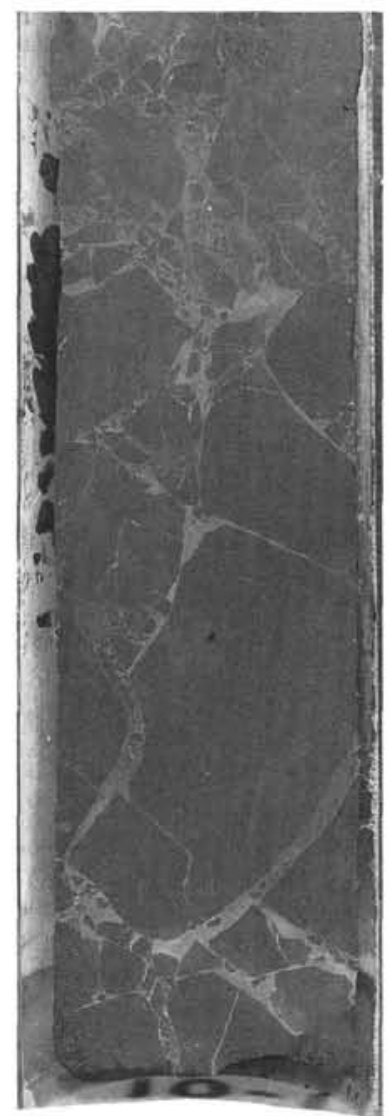

A

$5 \mathrm{~cm}$
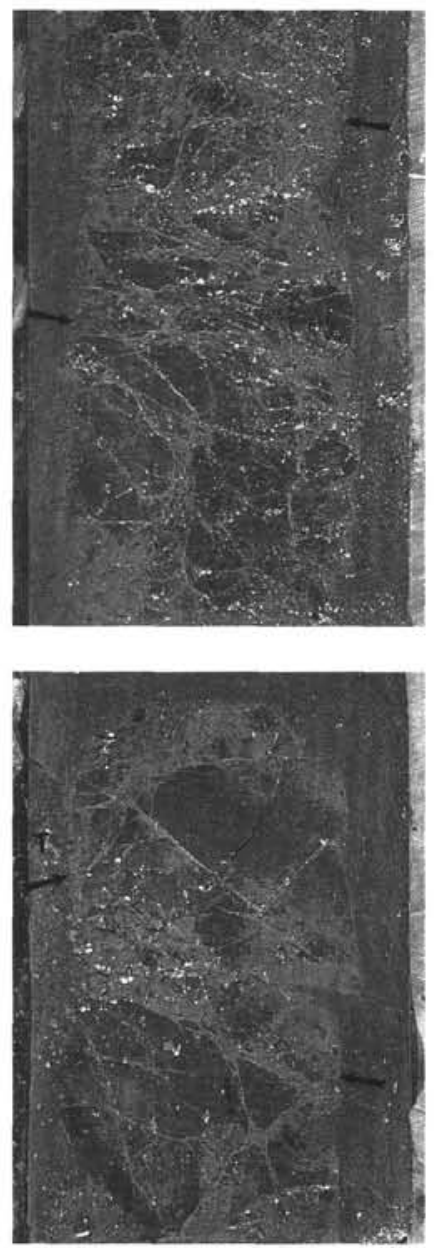

B
Figure 3. A. Carbonate breccia, pervasively cemented. Note interlocking angular clasts cut by random-to-subparallel brittle fractures and injected with white carbonate cement, evidently caused by forearc tectonism (112-688E-10R-1, 0-20 cm) B. Consolidated mudstone showing very similar, chaotic brittle-fracture patterns. Textural and compositional differences between the sedimented fractures and surrounding drill slurry, and sharply defined "biscuit" boundaries (arrows) suggest that the breccia fabrics existed prior to drillinginduced deformation (112-682A-38X-3, 13-23 cm, and 43-55 cm).

mineralogically distinct from the enclosing drill slurry, but identical in composition to the adjacent breccia blocks. Specifically, the clasts and matrix contain appreciable dolomiteprobably an incipient, friable cement-but the drill slurry is devoid of this mineral. The random, interlocking fracture pattern has a compelling similarity to the pervasively cemented carbonate breccias that are the focus of our study (Fig. 3). Like the cemented breccias, the fractured mudstones may have suffered dilational shatter, but internal sedimentation of the fracture porosity by disaggregation of the host sediment may have sealed the fractures from percolating and precipitating pore waters.

The distribution of brecciated carbonates on the Peru margin is controlled primarily by the regional structure of the forearc. Large volumes of brecciated carbonates were recovered from the Trujillo Basin (Fig. 1, Site 684; Fig. 2A, Dredges $35,54,59)$, as this basin has experienced a complex history of superimposed compressional and extensional tectonism. In general, the degree of brecciation (e.g., number of episodes of cross-cutting fracture cementation, volumetric ratio of frac- ture cement vs. groundmass blocks, intensity of granulation) increases toward the trench, due to increasingly pervasive fracturing associated with subduction erosion and collapse at the leading edge of the continental block (Fig. 1, Sites 682, 683, 685, 688; Fig. 2B, Dredges 18, 16, 17).

While the ODP boreholes were generally positioned in the depositional centers of sedimentary basins, site-survey dredges were recovered from outcrops along fault-bounded structural ridges at the basin margins (Figs. 1,2). The dredged rocks exhibit unusually complex histories of multigeneration fracturing and granulation (Fig. 4), evidently caused by repeated, episodic rupture along recurrently active fault zones. The cements from these samples hold the greatest potential for characterizing pore fluids of deep hydrologic reservoirs that have been advected to shallow levels along high-angle, normal faults in the subsiding continental block, or low-angle thrust faults in the accretionary prism that may be rooted in the décollement zone.

\section{METHODS}

The temporal sequence of diagenetic events was first established by petrographic relationships (Folk, 1965; Choquette and Pray, 1970; Bathurst, 1975). Cement generations were discriminated based on the following criteria: (1) distinct changes in cement morphology or crystal size; (2) the superposition sequence above a free surface, such as the wall of a fracture pore or the surface of a framework grain in an interparticle pore (Fig. 5); (3) truncation relationships with tectonic or lithostatic (compaction) features, especially the overprinting of successive fracturing episodes (Fig. 6); (4) interruption of the cementation process by internal sedimentation of the pore spaces (Figs. 5, 6); and (5) changes in the clarity of the cement, i.e., in the quantity of clay impurities derived from disaggregation of the host rock and entrained by the cementing fluid.

Individual cement generations were isolated for mineralogic and isotopic characterization on the basis of the petrographic observations. Millimeter-sized fracture and particle cements were separated using a fine diamond band saw and checked for purity under a binocular microscope. Carbonates sampled from the interparticle pores of sands and gravels (P), the aphanitic groundmass of breccia blocks (G), and the successive generations of fracture-filling cement $(\mathrm{C} 1, \mathrm{C} 2$, C3 ...) are indicated in Table 1 . The cements then were analyzed by standard X-ray diffraction techniques to estimate the relative abundances of calcite and poorly ordered dolomite phases, and the degree of cation substitution (mostly magnesium and possibly iron) in the carbonate lattice (Gensmer and Weiss, 1980). Although we report a precision of $\pm 0.1 \mathrm{~mol} \%$ for the carbonate mineral chemistry, the accuracy is probably not better than $\pm 1 \mathrm{~mol} \%$, based on laboratory standards measured over many years and with different instrumentation. Carbon and oxygen isotopic compositions $\left(\delta^{13} \mathrm{C}\right.$ and $\left.\delta^{18} \mathrm{O}\right)$ were determined using a Finigan Mat 251 mass spectrometer at the isotope facility of the Marine Geology group at Oregon State University. The results are reported relative to the PDB standard. The accuracy of both $\delta^{13} \mathrm{C}$ and $\delta^{18} \mathrm{O}$ determinations is estimated at $\pm 0.1 \%$, with somewhat higher precision. Replicate analyses that showed larger deviations may be caused by sample inhomogeneity or the "memory effect" that results from the back-to-back analysis of samples having widely discrepant isotopic compositions (Table 1).

\section{RESULTS AND DISCUSSION}

Carbonate mineralogies range from calcites with 0.4 to 7.7 mol\% magnesium, to dolomites with 33.4 to $51.7 \mathrm{~mol} \%$ magnesium (Table 1). Hi-Mg and Lo-Mg calcites are differen- 


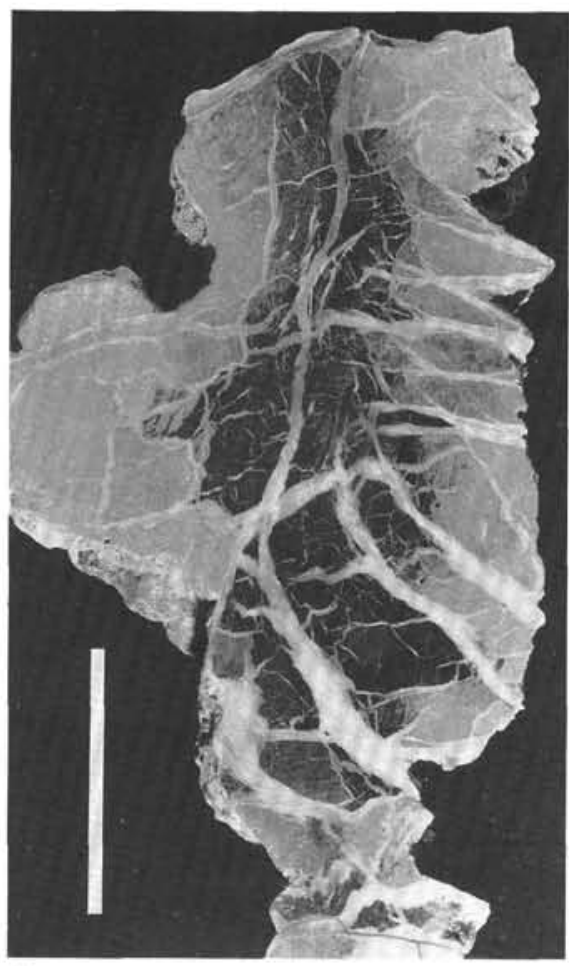

A

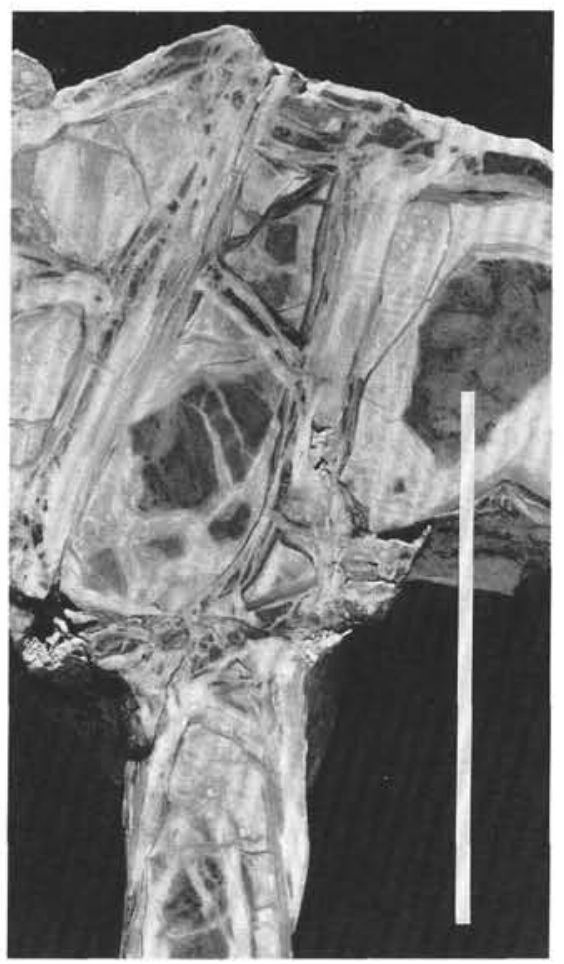

B

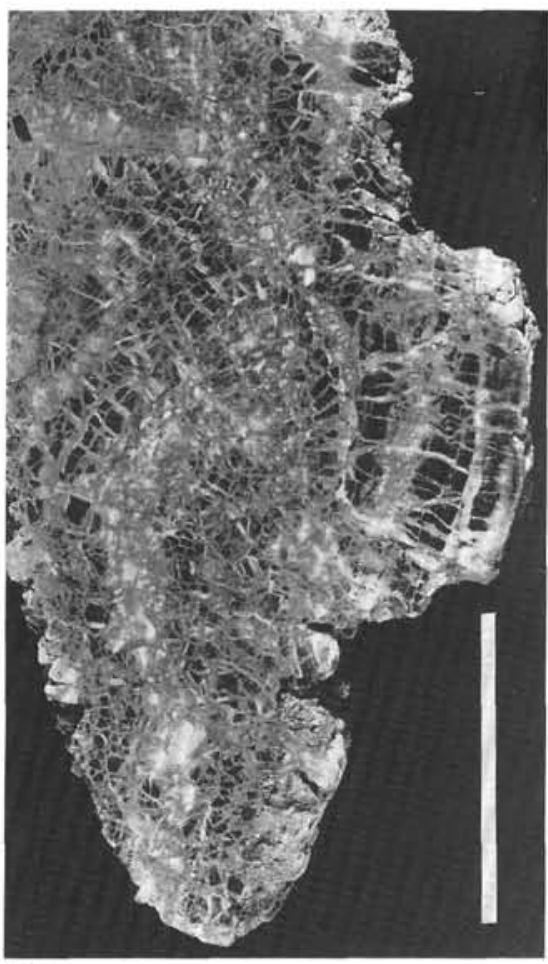

C

Figure 4. Polished sections of dredged rocks showing the progressive seaward increase in brecciation intensity from the upper slope (left) to the inner trench wall (right). Scale bar is $5 \mathrm{~cm}$ in all cases; see Figure 2B for dredge locations. A. Dark, aphanitic carbonate, fractured and intruded by a single generation of white cement (Dredge 3, \#19). B. Carbonate breccia with high cement/clast ratio, cut by multiple fracturing episodes and cemented by both dolomite and chert (Dredge 16, \#19). C. Carbonate microbreccia pervasively granulated by repeated tectonism (Dredge 17, \#10).

tiated at $5 \mathrm{~mol} \%$ magnesium, although cation substitution is continuous and gradational. The lowest values of magnesium content are found in Eocene cements from Site 688 and late Miocene cements from Sites 679 and 685 . Dolomites typically exhibit moderate amounts of calcium enrichment ( 40 to 45 $\mathrm{mol} \% \mathrm{Mg}$ ). Dolomites with near-perfect stoichiometry (47 to $52 \mathrm{~mol} \% \mathrm{Mg}$ ) are less frequently encountered, and extreme calcium enrichment is rare $(<40 \mathrm{~mol} \% \mathrm{Mg})$. Generally, the carbonate cements become richer in calcium with successively younger generations; both calcite and dolomite phases support this trend (e.g., 112-681A-12H-1, $20 \mathrm{~cm}$; 112-682A29X-1, $8 \mathrm{~cm}$; 112-685A-42X-CC, $24 \mathrm{~cm}$; and 112-688E-45R-1, $2 \mathrm{~cm}$ ). Other cementation sequences show no consistent trend or exhibit temporal stability, i.e., the mineralogy of sequential events varies by less than $1 \mathrm{~mol} \%$.

The broad span of $\delta^{13} \mathrm{C}$ values-from -20.6 to $+19.0 \%$ PDB - suggests that carbonate ions are derived primarily from the decomposition of sedimentary organic matter (Table 1; Fig. 7). Several microbial decomposition processes can drive carbonate cementation, including sulfate reduction, carbonate reduction, and direct oxidation of biogenic methane (Irwin et al., 1977; Suess et al., 1987).

The $\delta^{18} \mathrm{O}$ values cluster into two broad fields, one with compositions enriched in the heavy oxygen isotope $(+1.5$ to $+6.7 \%$, averaging $+4.5 \%$ ) and the other depleted in ${ }^{18} \mathrm{O}(-7.5$ to $+0.4 \%$, averaging $-3.5 \%$ ). Positive or "heavy" oxygen isotope ratios are characteristic of authigenic carbonates formed during early marine diagenesis in the shallow subsurface, at near bottom-water temperatures. Negative or "light" isotopic ratios may be influenced by recharging meteoric waters (salinity effect), geochemical alteration of mafic rocks (composition effect), or elevated temperatures in deeply buried diagenetic environments (temperature effect). Other criteria, such as cement morphology and mineralogy, the stratigraphic position of the sample, the structural setting and tectonic history of the site, must therefore be used in conjunction with isotopic data to constrain interpretations of fluid sources and transport pathways.

\section{Authigenic Marine Cements: Diagenesis by Microbial Sulfate Reduction and Carbonate Reduction}

Intense coastal upwelling and high biologic productivity in the water column along the Peru margin provide a large flux of organic matter to the seafloor, which quickly exhausts the oxygen content of the bottom waters (Kulm et al., 1984; Suess et al., 1987). Subsurface diagenetic reactions are driven by the anaerobic decomposition of organic matter by microbial sulfate- and carbonate-reduction mechanisms. The sulfate-reduction zone extends to depths between 17 and 100 $\mathrm{m}$ below the seafloor ( $\mathrm{mbsf}$ ) and is normally succeeded by the zone of methanogenesis by carbonate reduction. The depth at which sulfate reduction yields to carbonate reduction, however, is mainly controlled by the bulk sedimentation rate (Suess et al., 1987; Suess, von Huene, et al., 1988). In essence, rapid rates of sedimentation cause the uppermost sediment column to pass quickly from the sulfate-reduction zone into the zone of carbonate reduction because the supply of bottom-water sulfate cannot keep pace with sulfate consumption. During slow sedimentation, the uppermost sediment column remains for a longer period of time within the sulfatereduction zone before eventually reverting to carbonate reduction at greater depth. 

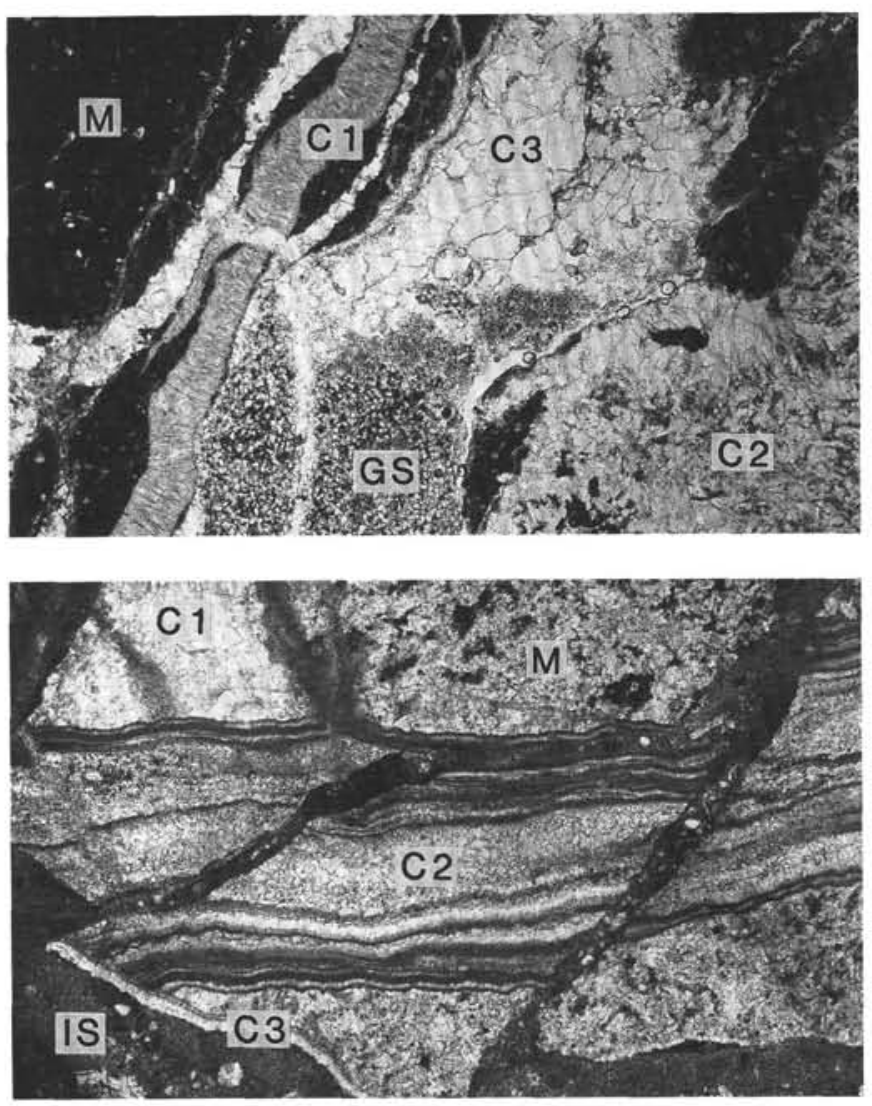

$1 \mathrm{~mm}$

Figure 5. Photomicrographs showing truncation relationships formed by successive fracturing episodes. TOP: Temporal sequence of cementation progressed from $\mathrm{C} 1$ (radial-fibrous spar) to $\mathrm{C} 2$ (interlocking rhombohedra) to C3 (coarse, equant spar). Fracture porosity formed during stage 3 was partially infilled by geopetal sediment (GS), which subsequently recrystallized to microspar (112-685A-51-X-CC, $44 \mathrm{~cm}$ ). BOTTOM: Recrystallized matrix material $(M)$ is sequentially cut by coarse spar (C1), growth-banded micrite and spar (C2), and isopachous rim cement (C3). The final stage of brecciation was filled by internal sediment (IS), which may have been contributed from nearsurface environments following exhumation of deeply buried strata at the seafloor along extensional faults (Dredge 17, 10).

The residual $\Sigma \mathrm{CO}_{2}$ accumulating during sulfate reduction is highly depleted in ${ }^{13} \mathrm{C}$, whereas $\mathrm{\Sigma CO}_{2}$ produced by the carbonate-reduction mechanism is enriched in ${ }^{13} \mathrm{C}$ (Irwin et al., 1977; Irwin, 1980; Pisciotto and Mahoney, 1981; Kelts and McKenzie, 1982; Baker and Burns, 1985). Authigenic cements precipitated within these diagenetic environments form thin, dense, aphanitic carbonates-sometimes termed "organic" carbonates-that record the metabolic signals of organic decomposition in their carbon isotopic ratios (Fig. 7: $S=$ sulfate reduction, $\mathbf{M}=$ methanogenesis). Carbonates precipitated in organic-rich muds beneath coastal upwelling zones on the Peru margin should thus evolve from initial compositions of strong ${ }^{13} \mathrm{C}$ depletion to an equally pronounced ${ }^{13} \mathrm{C}$ enrichment with increasing time and depth of burial.

The isotopic compositions of carbonates recovered during the Leg 112 drilling program document the depth succession of sulfate- and carbonate-reduction mechanisms during early marine diagenesis (Table 2 ). The pore-water sulfate and methane profiles at Sites 687 and 682 delineate the shallow zone of sulfate reduction (i.e., $<35$ mbsf at Site $687,<75$ mbsf at Site 682 ) and the dominance of carbonate reduction at depth. The
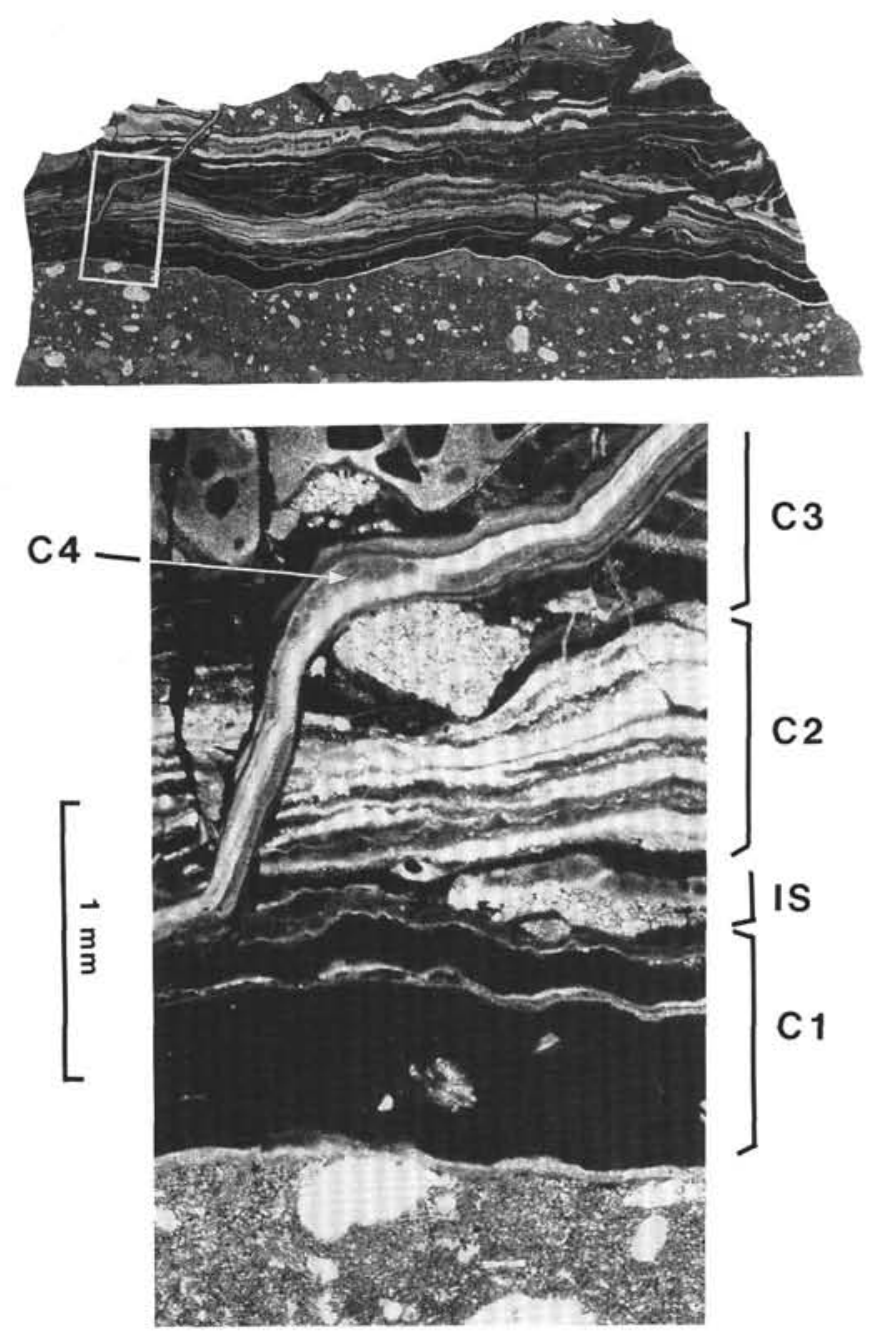

Figure 6. Laminated carbonate cements tainted with disseminated black opaques and exhibiting multigeneration superposition relationships. Polished slab above and photomicrograph below. The matrix is micritic carbonate with spar-filled foraminiferal molds. Cement zones $\mathrm{C} 1, \mathrm{C} 2$, and $\mathrm{C} 3$ are separated by discontinuity surfaces that may indicate periods of corrosion, and a fourth generation of fracturefilling cement (C4) cuts all previous growth zonations. Zones $\mathrm{Cl}$ and $\mathrm{C} 2$ are locally separated by a lens of internal sediment (IS), and zone C3 is internally brecciated (112-684A-13-CC, $0-3 \mathrm{~cm})$.

$\delta^{13} \mathrm{C}$ values of metabolic carbonate ions are recorded in authigenic dolomite cements in isotopic equilibrium with the subsurface pore waters. The composite depth succession of carbonate $\delta^{13} \mathrm{C}$ values in Holes $687 \mathrm{~B}$ and $682 \mathrm{~A}$ documents the initial formation of isotopically light cement within the sulfatereduction environment ( $-20.1 \%$ PDB), followed by progressive enrichment of ${ }^{13} \mathrm{C}$ in cements precipitated from the residual, dissolved $\Sigma \mathrm{CO}_{2}$ pool as methanogenesis proceeds $(+17.4 \%$ PDB $)$. Authigenic dolomites from the Peru margin thus span a broad range of ${ }^{13} \mathrm{C}$ composition $(-20.1$ to $+18.6 \%$ PDB) resulting from microbial fractionation during organicmatter decomposition, but a narrow band of ${ }^{18} \mathrm{O}$ composition $(+2.7$ to $+6.6 \%$ PDB $)$, indicating cementation at shallow subsurface temperatures in contact with normal marine pore waters (Fig. 7).

The morphological and structural configuration of the continental margin imparts a regional signal to the marine cements as well. The Trujillo Basin of north-central Peru is a stable platform undergoing slow sedimentation and intermit- 
Table 1. Stable carbon and oxygen isotopic ratios (relative to PDB) and XRD mineralogy (carbonate phase and mol\% Mg substitution) of Cenozoic cements recovered during Leg 112 drilling.

\begin{tabular}{|c|c|c|c|c|c|c|c|}
\hline $\begin{array}{l}\text { Core, sample, } \\
\text { interval, }(\mathrm{cm})^{\mathrm{a}}\end{array}$ & & $\begin{array}{l}\text { Depth }{ }^{b} \\
\text { (mbsf) }\end{array}$ & Mineralogy & $\delta^{13} \mathrm{C}$ & $\delta^{18} \mathrm{O}$ & $\% \mathrm{Mg}(\mathrm{Fe})$ & Age \\
\hline \multirow[t]{3}{*}{$112-679 \mathrm{D}-12 \mathrm{H}-1,40$} & $\mathrm{P}$ & 103.3 & Lo-Mg-calc. & -11.4 & -0.9 & 3.2 & Late Miocene \\
\hline & $\mathrm{Cl}$ & & Lo-Mg-calc. & -14.0 & -0.3 & 2.1 & \\
\hline & $\mathrm{C} 2$ & & Lo-Mg-calc. & -8.7 & 0.4 & 3.2 & \\
\hline 679E-3X-CC, 30 & P & 263.1 & Very Ca-rich dolom. & -5.0 & -1.4 & 38.5 & Middle Miocene \\
\hline $679 \mathrm{E}-10 \mathrm{X}-\mathrm{CC}, 26$ & P & 331.9 & Hi-Mg-calc. & -4.8 & -4.5 & 5.3 & Middle Miocene \\
\hline $680 \mathrm{E}-04 \mathrm{H}-06,75$ & P & 32.8 & Biogenic calc. & -2.7 & 1.5 & $<1.0$ & Quaternary \\
\hline $680 \mathrm{E}-07 \mathrm{H}-03,99$ & P & 57.0 & Ca-rich dolom. & -10.4 & 5.4 & 44.8 & Pliocene \\
\hline $680 \mathrm{~B}-12 \mathrm{X}-\mathrm{CC}, 22$ & P & 92.2 & Ca-rich dolom. & -2.9 & 4.0 & 44.1 & Pliocene \\
\hline $680 \mathrm{E}-19 \mathrm{X}-\mathrm{CC}, 20$ & P & 157.7 & Ca-rich dolom. & 4.9 & 4.8 & 44.4 & Pliocene \\
\hline \multirow[t]{4}{*}{$681 \mathrm{~A}-12 \mathrm{H}-01,20$} & G & 101.7 & Ca-rich dolom. & -12.0 & 4.8 & 44.8 & Quaternary \\
\hline & $\mathrm{Cl}$ & & Ca-rich dolom. & -11.0 & 4.7 & 41.8 & \\
\hline & $\mathrm{C} 2$ & & Ca-rich dolom. & -7.5 & 4.2 & 40.7 & \\
\hline & $\mathrm{C} 3$ & & Very Ca-rich dolom. & -11.1 & 3.7 & 33.4 & \\
\hline $682 \mathrm{~A}-13 \mathrm{X}-01,16$ & G & 114.5 & Stoichiom. dolom. & 1.8 & 6.7 & 49.0 & Late Miocene \\
\hline $682 \mathrm{~A}-21 \mathrm{X}-01,101$ & G & 191.3 & Stoichiom. dolom. & 16.4 & 4.2 & 48.5 & Middle Miocene \\
\hline \multirow[t]{3}{*}{$682 \mathrm{~A}-29 \mathrm{X}-01,8$} & G & 266.4 & Stoichiom. dolom. & 10.8 & 5.2 & 47.3 & Middle Miocene \\
\hline & $\mathrm{C} 1$ & & Ca-rich dolom. & 17.5 & 4.3 & 42.7 & \\
\hline & $\mathrm{C} 2$ & & Ca-rich dolom. & 18.6 & 4.2 & 42.7 & \\
\hline $682 \mathrm{~A}-35 \mathrm{X}-03,100$ & G & 315.3 & Stoichiom. dolom. & 17.4 & 4.8 & 48.6 & Middle Miocene \\
\hline \multirow[t]{2}{*}{$682 \mathrm{~A}-44 \mathrm{X}-\mathrm{CC}, 20$} & $\mathrm{P}$ & 397.3 & Hi-Mg-calc. & 19.0 & -5.8 & 7.2 & Oligocene \\
\hline & C & & Hi-Mg-calc. & 3.0 & -4.9 & 5.0 & \\
\hline $682 \mathrm{~A}-48 \mathrm{X}-01,21$ & $\mathrm{P}$ & 427.4 & Lo-Mg-calc. & 3.3 & -3.7 & 4.9 & Middle Eocene \\
\hline \multirow{2}{*}{ 683E-06X-CC, 26} & G & 453.2 & Hi-Mg-calc. & 3.3 & -2.4 & 5.1 & Middle Eocene \\
\hline & C & & & 8.5 & -1.4 & & \\
\hline duplicate & C & & & $(8.2)$ & $(-1.2)$ & & \\
\hline \multirow{3}{*}{$\begin{array}{l}\text { 684A-09X-01, } 105 \\
\text { duplicate }\end{array}$} & G & 70.7 & & 4.4 & 4.3 & & Middle Miocene \\
\hline & G & & & $(4.7)$ & (3.9) & & \\
\hline & $\mathrm{Cl}$ & & & -7.4 & 2.7 & & \\
\hline \multirow[t]{3}{*}{ duplicate } & $\mathrm{C} 1$ & & & $(-7.7)$ & $(2.2)$ & & \\
\hline & $\mathrm{C} 2$ & & Very Ca-rich dolom. & 1.2 & 3.2 & 39.5 & \\
\hline & C3 & & & 5.2 & 3.9 & & \\
\hline duplicate & $\mathrm{C} 3$ & & & (4.9) & (3.9) & & \\
\hline \multirow[t]{2}{*}{$684 \mathrm{~A}-15 \mathrm{X}-\mathrm{CC}, 14$} & $\mathrm{G}$ & 126.7 & Stoichiom. dolom. & 14.4 & 4.2 & 51.7 & Middle Miocene \\
\hline & $\mathrm{Cl}$ & & Stoichiom. dolom. & 13.6 & 4.0 & 48.9 & \\
\hline \multirow[t]{3}{*}{$685 \mathrm{~A}-42 \mathrm{X}-\mathrm{CC}, 24$} & $\mathrm{G} / \mathrm{C} 1$ & 378.9 & Lo-Mg-calc. & 4.1 & -1.3 & 4.4 & Late Miocene \\
\hline & $\mathrm{C} 2$ & & Lo-Mg-calc. & 3.5 & -1.8 & 3.3 & \\
\hline & $\mathrm{C} 3$ & & Lo-Mg-calc. & 3.9 & -1.1 & 2.1 & \\
\hline $685 \mathrm{~A}-50 \mathrm{X}-\mathrm{CC}, 31$ & G & 450.9 & Lo-Mg-calc. & -20.6 & -0.6 & 4.7 & Late Miocene \\
\hline & $\mathrm{C} 1$ & & Lo-Mg-calc. & -20.1 & -0.5 & 3.2 & \\
\hline & $\mathrm{C} 2$ & & Lo-Mg-calc. & -15.1 & -1.3 & 4.2 & \\
\hline & $\mathrm{C} 3$ & & Lo-Mg-calc. & -18.1 & -1.5 & 0.4 & \\
\hline $685 \mathrm{~A}-51 \mathrm{X}-\mathrm{CC}, 42$ & $\mathrm{P}$ & 459.5 & & -1.3 & -2.8 & & Late Miocene \\
\hline duplicate & $\mathrm{P}$ & & & $(-2.3)$ & $(-6.9)$ & & \\
\hline & C & & & -0.8 & -1.7 & & \\
\hline duplicate & C & & & $(-0.7)$ & $(-1.8)$ & & \\
\hline $686 \mathrm{~B}-16 \mathrm{X}-03,3$ & $\mathrm{P}$ & 144.5 & Ca-rich dolom. & 2.9 & 4.6 & 42.6 & Quaternary \\
\hline & C & & Ca-rich dolom. & 17.1 & 4.9 & 43.3 & \\
\hline 686B-28X-06, 121 & P & 264.2 & Ca-rich dolom. & 8.1 & 5.2 & 42.9 & Quaternary \\
\hline $687 \mathrm{E}-05 \mathrm{H}-01,29$ & G & 34.0 & Ca-rich dolom. & -20.1 & 6.6 & 44.8 & Quaternary \\
\hline $687 \mathrm{E}-07 \mathrm{H}-03,57$ & $\mathrm{P}$ & 56.3 & Ca-rich dolom. & -12.3 & 5.6 & 44.2 & Quaternary \\
\hline 687E-20X-01, 38 & $\mathrm{P}$ & 167.2 & Ca-rich dolom. & 1.1 & 5.3 & 44.7 & Pliocene \\
\hline 688E-30R-CC, 12 & P & 623.4 & Hi-Mg-calc. & -4.5 & -5.2 & 7.7 & Middle Eocene \\
\hline & $\mathrm{Cl}$ & & Lo-Mg-calc. & 1.9 & -4.4 & 3.9 & \\
\hline $688 \mathrm{E}-33 \mathrm{R}-02,131$ & $\mathrm{P}$ & 652.8 & Lo-Mg-calc. & 1.1 & -2.4 & 4.5 & Middle Eocene \\
\hline & (C1) & & Lo-Mg-calc. & 3.2 & -3.1 & 3.4 & \\
\hline & $\mathrm{C} 2$ & & Lo-Mg-calc. & 3.4 & -3.0 & 4.9 & \\
\hline 688E-34R-01, 114 & $\mathrm{P}$ & 660.6 & Lo-Mg-calc. & -0.4 & -5.6 & 4.7 & Middle Eocene \\
\hline & $\mathrm{C} 1$ & & Hi-Mg-calc. & 1.8 & -4.6 & 5.5 & \\
\hline & (C2) & & Lo-Mg-calc. & -0.1 & -5.6 & 3.0 & \\
\hline $688 \mathrm{E}-36 \mathrm{R}-02,13$ & $\mathrm{P}$ & 680.1 & Hi-Mg-calc. & 4.3 & -4.4 & 5.2 & Early Eocene \\
\hline & $\mathrm{C} 1$ & & & 7.8 & -5.3 & & \\
\hline duplicate & $\mathrm{C} 1$ & & & (7.9) & $(-4.7)$ & & \\
\hline & $\mathrm{C} 2$ & & Lo-Mg-calc. & 4.5 & -4.7 & 2.0 & \\
\hline $688 \mathrm{E}-37 \mathrm{R}-01,24$ & $\mathrm{P}$ & 688.2 & Lo-Mg-calc. & 3.1 & -7.3 & 4.7 & Early Eocene \\
\hline & C & & & 3.2 & -6.8 & & \\
\hline $688 \mathrm{E}-41 \mathrm{R}-01,45$ & G & 726.5 & Lo-Mg-calc. & -13.1 & -6.7 & 3.8 & Early Eocene \\
\hline & $\mathrm{C} 1$ & & Lo-Mg-calc. & -2.9 & -7.5 & 0.9 & \\
\hline duplicate & $\mathrm{Cl}$ & & Lo-Mg-calc. & $(-2.8)$ & $(-6.6)$ & & \\
\hline & $\mathrm{C} 2$ & & Lo-Mg-calc. & 3.4 & -7.0 & 3.0 & \\
\hline $688 \mathrm{E}-45 \mathrm{R}-01,2$ & G & 764.0 & Hi-Mg-calc. & 0.5 & -1.8 & 6.4 & Early Eocene \\
\hline & $\mathrm{C} 1$ & & Hi-Mg-calc. & 4.6 & -5.8 & 5.5 & \\
\hline & $\mathrm{C} 2$ & & Lo-Mg-calc. & 4.1 & -5.8 & 4.1 & \\
\hline
\end{tabular}

a Cement types isolated from ODP samples were coded as follows: $\mathrm{G}=$ groundmass blocks in carbonate breccias, $\mathrm{P}=$ interparticle cement in clastic lithologies, $\mathrm{C1}, \mathrm{C} 2, \mathrm{C} 3=$ sequential generations of fracture cement.

b Subsurface sample depths in meters below seafloor. 


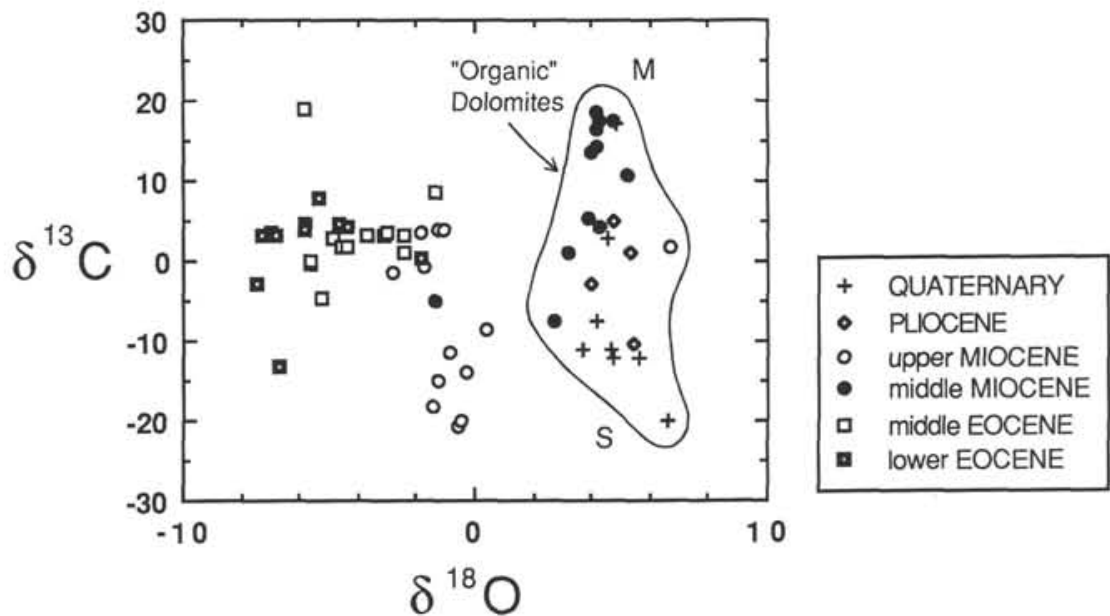

Figure 7. Isotopic $\delta^{13} \mathrm{C}$ and $\delta^{18} \mathrm{O}$ values (PDB) of Peru margin carbonates recovered during Leg 112 (see Table 1). "Organic" dolomites form during the early stages of marine diagenesis in upwelling sediments and record isotopic signatures imparted by the microbial decomposition mechanisms of sulfate reduction (S) and methanogenesis (M); these cements exhibit a wide range of ${ }^{13} \mathrm{C}$ compositions, but a narrow band of enriched ${ }^{18} \mathrm{O}$ compositions. See text for further explanation of isotopic distributions.

Table 2. Pore-water chemistry and isotopic compositions (relative to PDB) of carbonate cements from Sites 687 and 682, Peru continental margin.

\begin{tabular}{cccccc}
\hline $\begin{array}{c}\text { Depth } \\
(\mathrm{mbsf})^{\mathrm{a}}\end{array}$ & $\begin{array}{c}\text { Salinity } \\
(\% \circ)\end{array}$ & $\begin{array}{c}\text { Sulfate } \\
(\mathrm{mmol})\end{array}$ & $\begin{array}{c}\text { Methane } \\
(\mathrm{ml} / \mathrm{L})\end{array}$ & $\begin{array}{c}\delta^{13} \mathrm{C} \\
(\% \circ)\end{array}$ & $\begin{array}{c}\delta^{18} \mathrm{O} \\
(\%)\end{array}$ \\
\hline Hole 687B & & & & & \\
$\quad 4-5$ & 34.8 & 19.3 & $\mathrm{tr}$ & & \\
$21-14$ & 34.0 & 6.8 & 0.16 & & \\
$32-37$ & 34.0 & 0.0 & 0.23 & -20.1 & +6.6 \\
$51-56$ & $\mathrm{~b} 35.0$ & 0.0 & 43.00 & -12.3 & +5.6 \\
$161-169$ & $\mathrm{~b} 46.1$ & 0.0 & 140.00 & +1.1 & +5.3 \\
& & & & & \\
Hole 682A & & & & & \\
$4-5$ & 34.0 & 24.7 & 0.03 & & \\
$23-24$ & 34.0 & 12.2 & 0.18 & & \\
$52-53$ & 34.0 & 4.4 & 57.00 & & +6.7 \\
$76-77$ & 33.6 & $(2.7)$ & 95.00 & & \\
$105-115$ & 33.2 & $(2.4)$ & 56.00 & +1.8 & +6.7 \\
$191-201$ & 32.2 & $(2.8)$ & 90.00 & +16.4 & +4.7 \\
$307-322$ & 32.0 & $(1.7)$ & 29.00 & +17.4 & +4.8 \\
\hline
\end{tabular}

a Depth interval from which pore water, gas, and carbonates were sampled.

${ }^{\mathrm{b}}$ Hypersaline fluids.

( $)=$ sulfate contaminated by seawater drilling fluid.

tent sediment winnowing by oxygenated bottom currents to form sandy, calcarenitic lag deposits at the seafloor (Figs, 1, $2)$. In contrast, the Lima Basin of south-central Peru has experienced extensive subsidence during the past $6 \mathrm{~m}$.y., and rapid sedimentation of diatomaceous, organic-rich muds with lesser amounts of disseminated calcareous detritus. Although the amount of primary biological productivity in the overlying water columns is comparable in both areas, the zone of sulfate reduction has been greatly expanded in the Trujillo Basin deposits, while the zone of carbonate reduction, and resulting methanogenesis, extends upward into shallow subsurface levels in the Lima Basin. As a consequence of these differences in the compositions of the host lithologies and the mechanisms of organic-carbon decomposition, the Lima Basin yielded near-stoichiometric dolomites enriched in the heavy-carbon isotope $\left(\delta^{13} \mathrm{C}=+2\right.$ to $+15 \%$ o $\left.\mathrm{PDB}\right)$, while the Trujillo Basin yielded calcium-rich dolomites and magnesium calcites with depleted carbon isotope ratios $\left(\delta^{13} \mathrm{C}=-2\right.$ to
$-30 \%$ PDB) (Kulm et al., 1984; Suess et al., 1987; Kulm et al., 1988).

Expansions and contractions of the subsurface diagenetic zones in response to changing oceanographic (upwelling intensity), tectonic (uplift and subsidence), eustatic (regressions and transgressions of sea level), or sedimentary conditions (fluvial discharge and dilution of biogenic influx) can cause, in addition, temporal modulations of the regional distributions and burial gradients. Organic dolomites formed mainly during periods of tectonic quiescence, subsidence, and biogenic sedimentation, and are common in strata of middle Miocene, Pliocene, and Quaternary age on the Peru margin (Fig. 7). Such dolomites did not generally form in the Eocene and late Miocene, when orogenic uplift, emergence, and increased terrigenous influx probably prevailed. Shallowmarine dolomites of Quaternary age are most depleted in ${ }^{13} \mathrm{C}$ and enriched in calcium, and probably precipitated during diagenesis in the sulfate-reduction zone (Fig. 8). The intermittent regressions of sea level during Quaternary glacial periods may have introduced periodic winnowing and oxygenation of the organic-rich sediments, concentrating carbonate tests and shells (and thus providing a calcium source) and facilitating the penetration of dissolved sulfate into the sediment column.

The general decrease in $\delta^{18} \mathrm{O}$ values with increasing subsurface depth is related to increasing formation temperatures during progressive burial (Fig. 9). Since much of the variance in the isotopic ratios is explained by the depth correlation, the use of the $\delta^{18} \mathrm{O}$ signal as a paleothermometer appears justified in a first-order approximation. Additional variability, however, is contributed to the ${ }^{18} \mathrm{O}$ record by competing and compounding factors-the salinity of the precipitating waters, isotopic exchange with the enclosing sediments, lithostatic unloading by erosional stripping at unconformities, and lithostatic overloading by stratal juxtaposition along accretionary thrusts or downslope emplacement of large slump blocks.

\section{Exotic Cements: Preliminary Interpretations of Fluid Sources}

The time-succession of carbonate cements (cement stratigraphy) filling fracture and interparticle porosity in coarse clastic sediments and tectonic breccias provides a valuable 

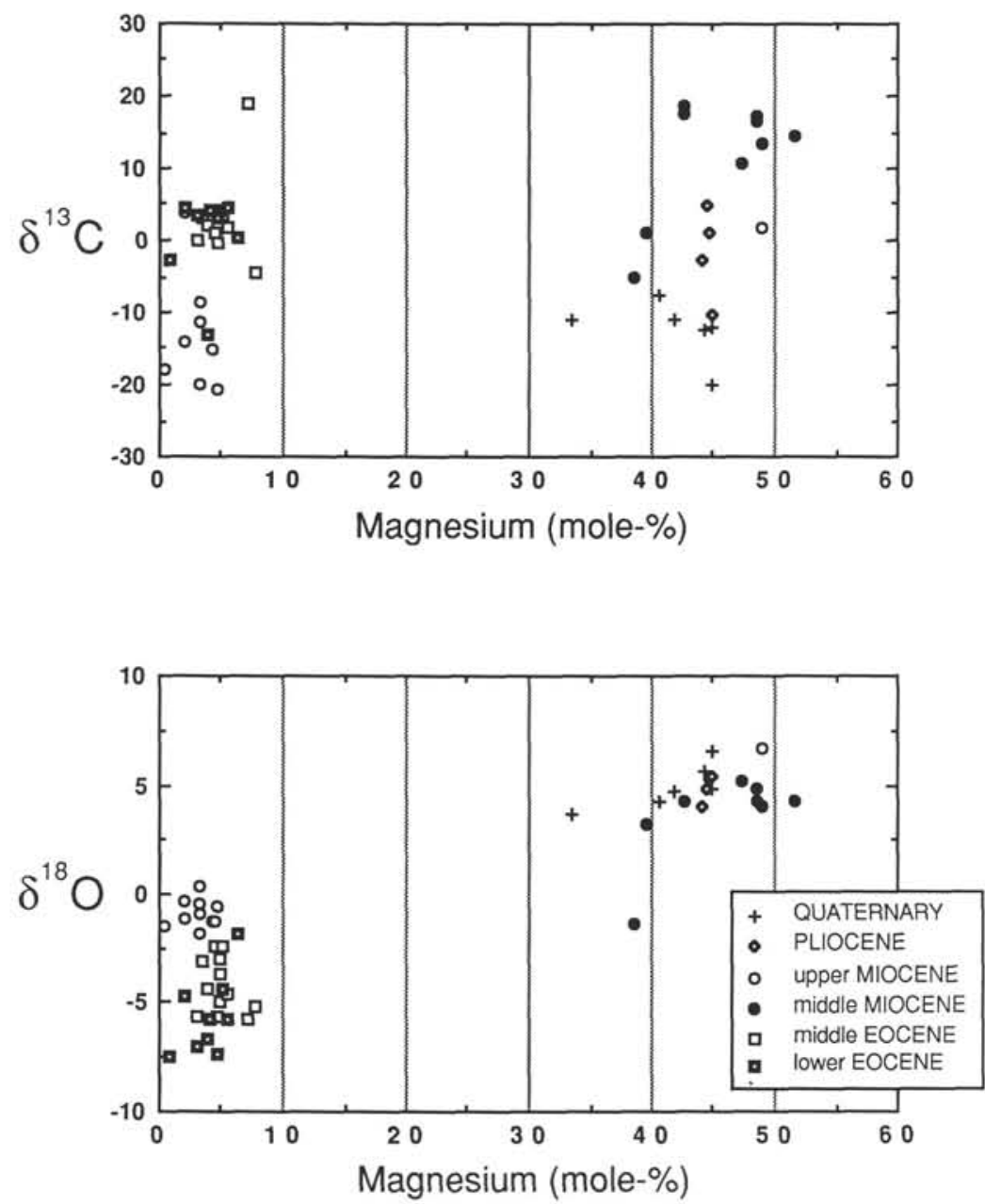

Figure 8. Isotopic $\delta^{13} \mathrm{C}$ and $\delta^{18} \mathrm{O}$ values (PDB) vs. mol\% magnesium substitution in the carbonate lattice. "Organic" carbonates of Figure 7 crystallize primarily as near-stoichiometric or calcium-rich dolomite, while Eocene and late Miocene cements of Lo-Mg calcite composition may have been influenced by meteoric recharge or basalt alteration.

record of the evolution of pore-water chemistry at the site of precipitation, and constrains interpretations of fluid sources and hydrogeologic processes in the Peruvian continental margin. Fluids influenced by sulfate reduction and methanogenesis typically induce precipitation of authigenic carbonates near the site of decomposition of organic-rich sediments, as discussed above. Reservoirs of such fluids trapped in porous muds, however, could escape into more permeable structures or lithologies and affect cementation processes at more distant sites as well. In addition, we tentatively identify four exotic cement types that may be derived from solutes transported in advecting pore fluids from their site of generation. These cements are related to the following diagenetic environments: (1) recharging meteoric waters, (2) low-temperature basalt alteration, (3) methane-oxidation during seafloor venting, and (4) hypersaline concentration. In particular, fluids from altered oceanic crust and hypersaline environments are postulated to exist below the levels sampled during Leg 112, so their signatures must be carried in fluids advected from depth and precipitated in exotic cements.

\section{Meteoric Waters and Subaerial Recharge}

Time-transgressive, regional unconformities during late Eocene/Oligocene and late Miocene time extend over much of the Peruvian continental margin, and correspond to periods of Andean orogenesis, uplift, and deformation onshore (von Huene, Suess et al., 1988). The post-middle Eocene (Sites $682,683,688$ ) and post-middle Miocene events (Sites 679, 683, 684,688 ) created stratigraphic hiatuses of up to 25 and $5 \mathrm{~m} . \mathrm{y}$. duration, respectively, and may have subjected contemporary and underlying strata to diagenesis by meteoric waters during subaerial exposure. Lower to middle Eocene sediments of Site 688 contain coarse sand and gravel with traction and scour structures, as well as fossil assemblages typical of inner continental-shelf environments (Hagn and Martini, this volume); these sediments were clearly deposited in shallow, nearshore waters, then subsided to present water depths in excess of $4000 \mathrm{~m}$.

The middle continental slope off Peru yielded Lo-Mg, sparry calcite cements having pendant, meniscus, and coarsely crystalline, bladed and blocky morphologies (Fig. 10), typical of vadose and phreatic environments of meteoric diagenesis (Longman, 1980). Carbonate cements derived from Eocene strata in Leg 112 drill holes, particularly lower Eocene strata, are most depleted in ${ }^{18} \mathrm{O}$ (to $-7.5 \%$ PDB), suggesting meteoric influence following uplift and emergence of the continental margin and, consequently, accelerated freshwater recharge in forearc basins (Figs. 7, 8). These samples 


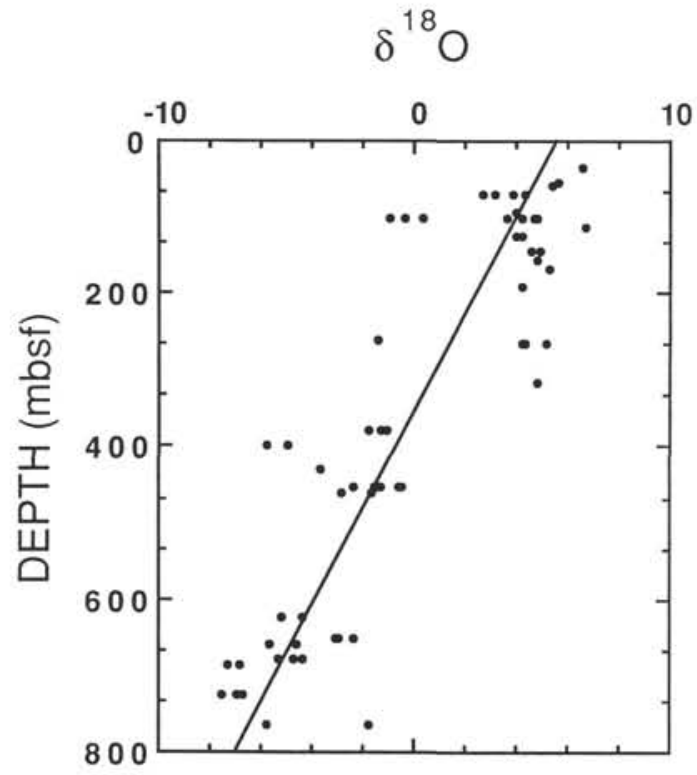

Figure 9. Isotopic $\delta^{18} \mathrm{O}$ values (PDB) vs. depth in meters below seafloor (mbsf). The good correlation $\left(r^{2}=0.79\right)$ indicates a primary influence of temperature on oxygen-isotope fractionation during carbonate precipitation. Additional variance may be explained by changes in the isotopic composition of pore fluids, salinity effects, isotopic exchange with the host sediments, and removal of overburden at unconformities.

exhibit a narrow range of $\delta^{13} \mathrm{C}$ values $(-1$ to $+5 \%$ PDB) that may be derived from a homogeneous groundwater reservoir, while a few more depleted values (to $-13.1 \%$ PDB) may have formed by incorporation of microbially derived $\mathrm{\Sigma CO}_{2}$ from an unsaturated soil zone (Fig. 8; Allan and Matthews, 1982). Generally, the most negative oxygen-isotope ratios and lowest values of magnesium substitution occur in the intermediate and late-stage cement generations of these Eocene strata (Table 1).

\section{Low-Temperature Basalt Alteration}

Submarine alteration of basaltic volcanics and volcaniclastics consumes magnesium and releases calcium, causing a substantial decrease in the magnesium/calcium ratio of the adjacent pore fluids (Lawrence et al., 1975; Gieskes and Lawrence, 1981; Gieskes et al., 1988). Disseminated or interbedded volcaniclastic detritus is common in the Peru forearc basins, and the diagenetic alteration of these unstable lithologies can decrease the dissolved magnesium content of the pore fluids (e.g., Site 688; Shipboard Scientific Party, 1988). Consequently, reduced magnesium substitution in the carbonate lattice could allow the growth of larger cement crystals by decreasing the effects of lattice distortion caused by the smaller cation (Folk and Land, 1975; Given and Wilkinson, 1985). In addition, the alteration of volcanics may cause a depletion of ${ }^{18} \mathrm{O}$ in the pore waters (Vrolijk et al., in press; Lawrence et al., 1975) that should be recorded in the $\delta^{18} \mathrm{O}$ values of the carbonate cements. Such ${ }^{18} \mathrm{O}$ depletion is obviously compounded if the temperature of cementation is elevated, as when fluids are advected against the geothermal gradient from deep-burial environments. Fluids generated below the forearc by interaction with the subducting oceanic crust should thus be deficient in magnesium, enriched in calcium, and depleted in ${ }^{18} \mathrm{O}$. These compositional and isotopic trends are fortuitously similar to those imparted by meteoric influences during carbonate cementation.
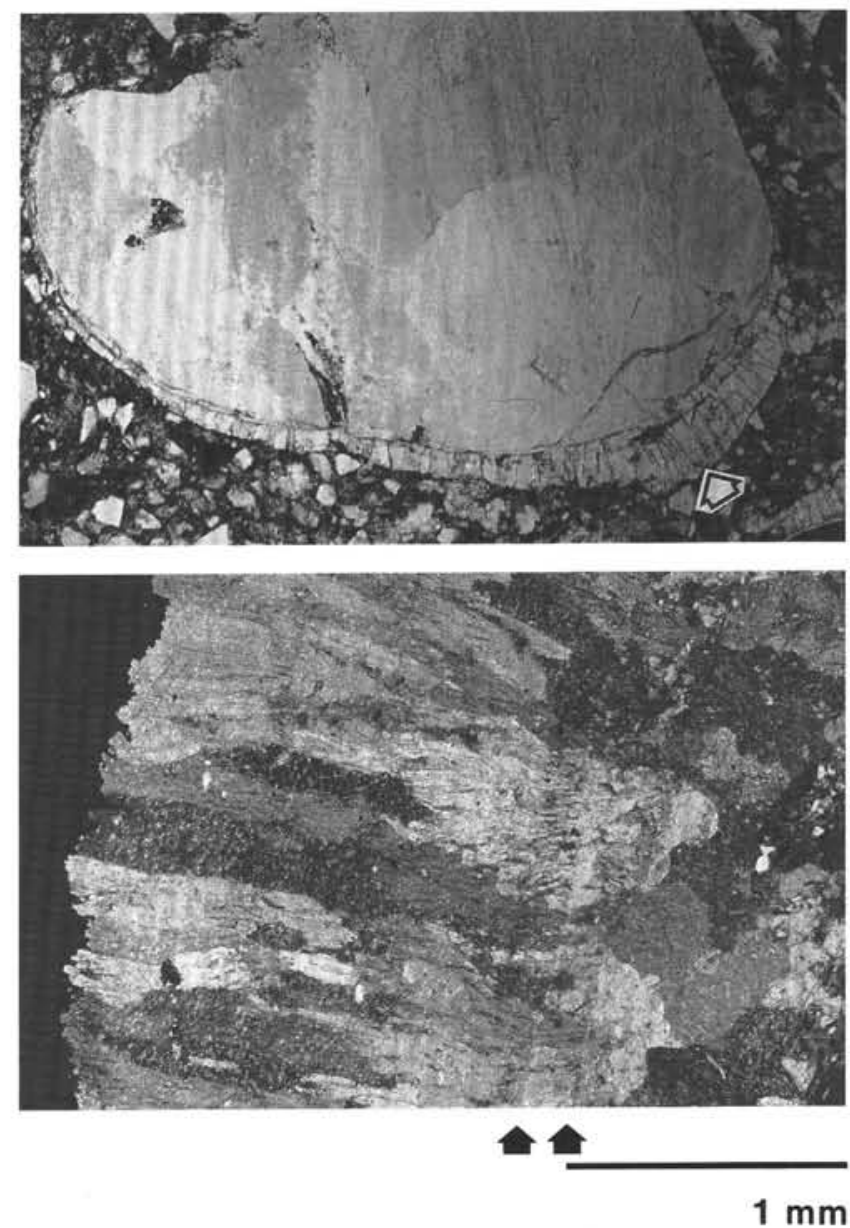

Figure 10. Petrographic evidence for meteoric diagenesis before subsidence to present water depths on the mid-to-lower continental slope. ABOVE: Pendant cement morphology, typical of vadose exposure, rimming quartzite clast in coarse-grained Eocene shelf sequence (112-688E-37-1, $24 \mathrm{~cm}$ ). BELOW: Coarse, bladed calcite exhibiting competitive growth fabric toward vacant pore at left; arrows denote growth discontinuities outlined by bands of clay-rich inclusions (photo under crossed nicols) (8506-DR25-48). These Lo$\mathrm{Mg}$ calcites are unusually depleted in the ${ }^{18} \mathrm{O}$ isotope.

Carbonates precipitated from geochemically altered fluids may include calcite cements in the upper Miocene strata of Sites 679 and 685 , which contain low mole-percentages of magnesium and depleted ${ }^{18} \mathrm{O}$ values (Figs. 7, 8; Table 1). The ${ }^{18} \mathrm{O}$-depletion is not as profound as that attributed to meteoric fluids, however, which impart a stronger salinity effect. Carbon isotopic values of late Miocene cements plot in a bimodal distribution-one mode between -8 and $-21 \%$ PDB and another between -2 and $+4 \%$ PDB-providing evidence for two distinct fluid sources, possibly from different source lithologies or burial levels (Fig. 7). Site 685 is positioned on the narrow accretionary prism along the landward wall of the trench, above a major thrust fault imaged in seismic-reflection records (von Huene and Miller, 1988) and therefore in the pathway of fluids ascending from the subduction zone that may have interacted with the descending oceanic crust. Orogenesis and accelerated convergence during late Miocene time (Cande, 1985; Pardo-Casas and Molnar, 1987) may have intensified onshore erosion, shelf bypassing, and trench sedimentation; the seaward growth, deformation, and dewatering of the accretionary complex; and the ascent of buried pore 


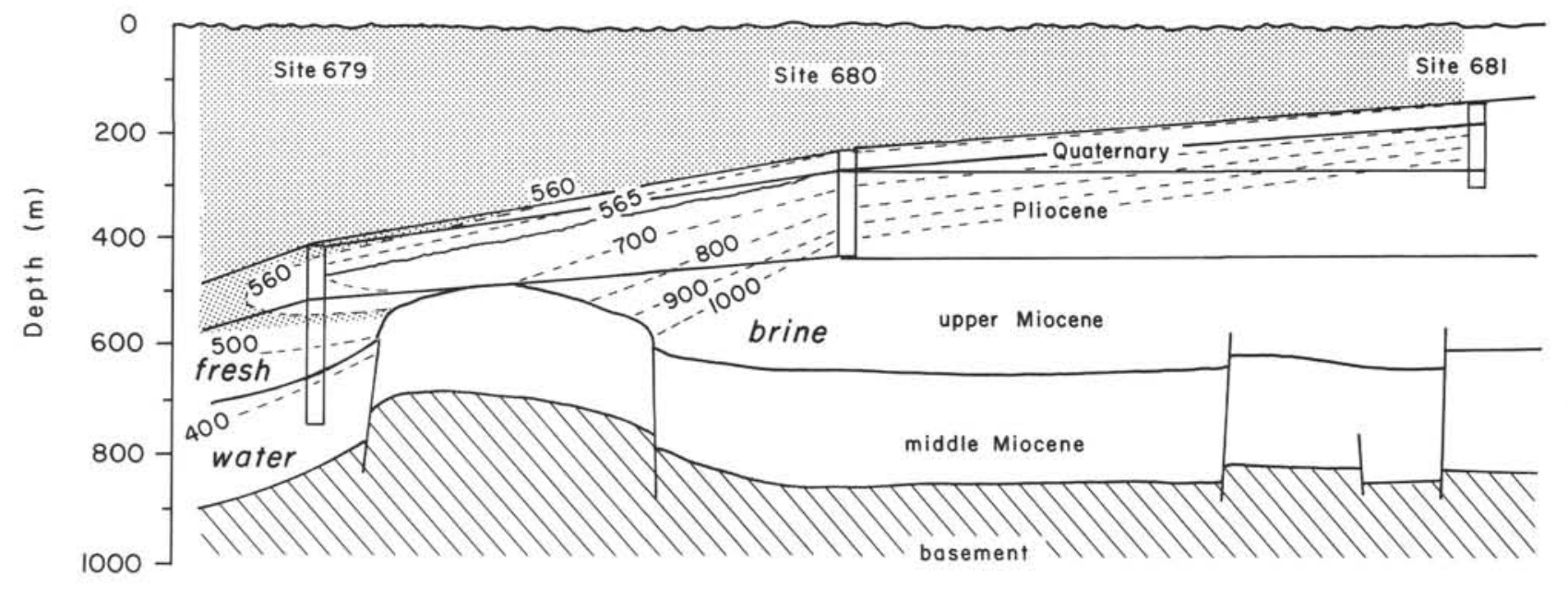

$$
\begin{array}{r}
<\text { isohalines ( } \mathrm{mM} \text { ) chloride } \\
550(\mathrm{mM}) \text { normal seawater chlorinity } \\
<100 \text { to } 550(\mathrm{mM}) \text { fresh water influence } \\
>100 \text { to } 550(\mathrm{mM}) \text { brine influence }
\end{array}
$$

Figure 11. Isohaline contours of pore-water chlorinities in a transect of Leg 112 drill holes across the Salaverry Basin on the continental shelf. Two contrasting hydrologic regimes are separated by an outer-shelf structural high (OSH of Figs. 1 and 2). One is dominated by hypersaline fluids (Sites 680,681 ) and the other by brackish waters (Site 679 below $600 \mathrm{~m}$ total depth). We hypothesize that subaerial exposure and reactivated uplift of this outer-shelf structure during late Miocene orogenic movements caused a restricted, evaporitic basin to form landward (Sites 680 and 681 ), while meteoric recharge along the ridge may have penetrated the strata at Site 679 on the seaward flank of the structure.

fluids through the overpressured sediment wedge (von Huene, Suess, et al., 1988).

\section{Venting of Marine Fluids at the Seafloor}

Carbonate cements formed by the microbial oxidation of methane are associated with seafloor vents on the continental slopes of both active and passive margins (Ritger et al., 1987; Suess and Whiticar, 1988; Kennicutt et al., 1985). Oxidation of biogenic and thermogenic methane generates $\Sigma \mathrm{CO}_{2}$, which is extremely depleted in ${ }^{13} \mathrm{C}$, i.e., less than $-35 \%$ PDB. The formation of methane-derived carbonates requires vertical transport of fluids from the subsurface environments of methane generation to the shallower zones of anaerobic decomposition via sulfate reduction, or aerobic decomposition via oxygen consumption by venting directly to the seafloor. Micritic, $\mathrm{Hi}-\mathrm{Mg}$ calcite cements recovered from fault-bounded structural ridges on the seaward flanks of the Lima and Trujillo basins yielded $\delta^{13} \mathrm{C}$ values as light as $-37.3 \%$ PDB and may provide evidence for the venting of methane-charged waters (Fig. 2: Dredges 18 and 35; Kulm et al., 1988)

During the site-survey program, live specimens of the giant white clam Calyptogena sp. were dredged from a crossmargin structure near the transition of the Lima and Trujillo basins (Fig. 2A: Dredge 25; Kulm et al., 1988). Like the carbonate cements from documented vent sites, the gill tissues of these organisms are strongly depleted in the heavy carbon isotope $\left(\delta^{13} \mathrm{C}=-38 \%\right.$ o PDB). Such clams have been discovered on accretionary prisms undergoing tectonic consolidation and sediment dewatering, including the OregonWashington (Kulm et al., 1986; Suess et al., 1985), Nankai, Japan, and Kuril subduction zones (Boulegue et al., 1987). A unique, chemosynthetic metabolism indicates that methane in expelled fluids is utilized as an energy and food source by symbiotic microbes in the clams. Unlike the accretionary settings of other vent systems, seafloor venting on the Peru margin is apparently exploiting near-vertical faults rooted in the continental massif.

\section{Hypersaline Fluids and Evaporative Basins}

At most drill sites on the continental shelf and upper slope of the Peru margin, marked downhole fluctuations in porewater salinities indicate a complicated subsurface hydrologic regime. Salinities observed in the Salaverry Basin on the continental shelf were more than double that of seawater. Figure 11 depicts, in vertical profile, the isohaline contours of pore-water chlorinities across the central Peru margin. Contrasting fluid regimes, one influenced by a subsurface saline brine on the shelf and the other by low-chloride water on the upper slope, are separated by an outer-shelf structural highthe offshore extension of the Coastal Cordillera (see Figs. 1, 2). We postulate that the source of the hypersaline fluids lies in upper Miocene strata landward of this barrier. Local subaereal exposure of the structural high during late Miocene orogenic movements (or at least reactivated uplift and relief on the basement horst blocks) may have formed a restricted, marginal sea over the continental shelf where the brine and possibly evaporites were concentrated. The brine's composition and subsurface distribution are not well known at present because of the sparse location of drill sites and inadequate penetration on the shelf. By providing dissolved sulfate and cations in excess of diffusive fluxes, brinal fluids can reestablish the microbial sulfate-reduction mechanism in deeper diagenetic environments, and induce precipitation of micritic dolomite and $\mathrm{Hi}-\mathrm{Mg}$ calcite.

The hypersaline fluids, if formed by evaporative concentration, should cause an enrichment of ${ }^{18} \mathrm{O}$ in carbonate cements. The observed downhole increases in pore-water salinity on the continental shelf, however, are accompanied by a simultaneous increase in burial temperature, and the two gradients produce opposite effects in the fractionation of the heavy oxygen isotope. At Site 687 , where borehole tempera- 
ture measurements are available $\left(12^{\circ} \mathrm{C}\right.$ at $34 \mathrm{mbsf}, 19^{\circ} \mathrm{C}$ at 167 mbsf), the oxygen-isotope signal of dolomitic cements can be separated into components of salinity-induced ${ }^{18} \mathrm{O}$ enrichment and temperature-induced ${ }^{18} \mathrm{O}$ depletion with increasing depth of burial (Table 2). The theoretical $\delta^{18} \mathrm{O}$ values expected for dolomite precipitation from normal marine fluids at the respective borehole temperatures (based on Fritz and Smith, 1970) are $4.5 \%$. PDB at 34 mbsf and $2.7 \%$ PDB at 167 mbsf. The differences between the calculated and observed values are thus 1.1 and $2.6 \%$ PDB, which correspond to salinity increases of 3 and $9 \% \mathrm{~S}$, respectively. These salinity estimates are in close agreement with measured increases in pore-water values of 2 and $12 \% \mathrm{~S}$ above normal marine seawater.

\section{Influence of Tectonics, Eustacy, and Climate on Fluid Migration}

High-angle normal faults resulting from subduction erosion and subsidence of the continental margin provide conduits by which fluids at depth may be rapidly advected to the shallow levels of forearc sedimentary basins. Cements precipitated along major through-going structures hold the greatest potential for preserving the compositions of deep-seated fluids, with minimal chemical alteration during transport. Such processes will be best developed near the toe of the continental block, where extensional collapse is exaggerated and normal faulting particularly pervasive. In contrast, ruptures formed by the compressional deformation of semiconsolidated, off-scraped sediments are probably more diffuse, tortuous, and less conductive of fluids. Slower rates of ascent and irregular, shallowdipping fault zones allow migrating fluids to react more thoroughly with the surrounding sediments, and carbonate cements should record more highly evolved fluids that have matured during transport from their initial compositions. Near-vertical, fold-axis cleavage fabrics, however, may provide more direct routes of vertical transport in accretionary prisms.

Hydrogeologic environments shift with transgressions and regressions of the coastline in response to episodes of tectonic uplift and subsidence, and changes in eustatic sea level. Eustatic signals should be best preserved in continental shelf and upper-slope environments that have undergone comparatively little vertical tectonic displacement since deposition. Tectonic signals should be best preserved in middle- and lower-slope sites that have undergone large vertical subsidence far in excess of the magnitude of changes in eustatic sea level.

Diagenesis by meteoric waters may be enhanced during glacial periods because a larger portion of the margin is subaerially exposed, and because the lowering of sea level causes an increase in the hydraulic gradient, which in turn induces a deeper and more active groundwater circulation. If climatic change is accompanied by increased precipitation, groundwater recharge is accelerated, causing the freshwater lens to expand and more effectively penetrate marine environments along confined aquifers. The establishment of a hot, arid climate may hinder the expansion of meteoric diagenesis, but may promote the concentration of hypersaline brines in restricted, marginal seas.

\section{CONCLUSIONS}

The intensity and persistence of forces that shaped the Peru continental margin are unique in the spectrum of activemargin scenarios-fast convergence rates, high organic influx from the coastal upwelling regime, a $200-\mathrm{m}$.y. history of subduction and orogeny, and an ancient continental foundation undergoing massive subsidence and collapse. Within this dynamic setting, we have identified two authigenic cements formed by microbial decomposition of organic matter (sulfatereduction and methanogenesis mechanisms) and potentially four exotic cements precipitated in the paths of migrating pore fluids. Cementation by meteoric, hypersaline, vented marine, and geochemically altered fluids is influenced to varying degrees by solute transport and subsurface advective processes.

Further documentation of pore-filling cement stratigraphies will establish time-, space-, and depth-dependent diagenetic gradients, and will help to advance our understanding of convergent-margin hydrogeologic processes. Increased sampling density, resolution, and quantification of cement morphologies and compositions using such tools as cathodoluminescence petrography, scanning-electron microscopy, and electron microprobe analysis should provide fruitful areas of future research. Interdisciplinary programs that combine carbonate diagenesis, fluid inclusion studies, pore-water chemistry, seismic stratigraphy, and sedimentology will further constrain interpretations of fluid sources. Such work should clarify the roles of subduction tectonics, eustacy, climate, and paleoceanography in the hydrologic development of the central Peru forearc during Cenozoic time.

\section{ACKNOWLEDGMENTS}

Our interpretations were seasoned by informal conversations with Leg 112 colleagues, and our manuscript benefited from the constructive comments of two anonymous reviewers. Andy Ungerer assisted in the generation of X-ray diffraction data, and Alan Mix and Bill Rugh helped with the isotopic analyses. Dan Orange generously experimented with cathodoluminescence techniques on some trial samples with successful results. This work was supported by a post-cruise grant from USSAC.

\section{REFERENCES}

Allan, J. R., and Matthews, R. K., 1982. Isotope signatures associated with early meteoric diagenesis. Sedimentology, 29:797-817.

Baker, P. A., and Burns, S. J., 1985. Occurrence and formation of dolomite in organic-rich continental margin sediments. AAPG Bull., 69:1917-1930.

Ballesteros, M. W., Moore, G. F., Taylor, B., and Ruppert, S., 1988. Seismic stratigraphic framework of the Lima and Yaquina forearc basins, Peru. In Suess, E., von Huene, R., et al., Proc. ODP, Init. Repts., 112: College Station, TX (Ocean Drilling Program), 77-90.

Bathurst, R.G.C., 1975. Carbonate Sediments and Their Diagenesis: New York (Elsevier).

Boulegue, J., Benedetti, E. L., Dron, D., Mariotti, A., and Lètolle, R., 1987. Geochemical and biogeochemical observations on the biological communities associated with fluid venting in Nankai Trough and Japan Trench subduction zones. Earth Planet. Sci. Lett., 83:343-355.

Bray, C. J., and Karig, D. E., 1985. Porosity of sediments in accretionary prisms and some implications for dewatering processes. $J$. Geophys. Res., 90:768-778.

Cande. S. C.. 1985. Nazca-South America Plate interactions. 50 m.y.b.p. to present. In Hussong, D. M., Dang, S. P., Kulm, L. D., Couch, R. W., and Hilde, T. C. (Eds.), Peru-Chile Trench off Peru, Atlas: Woods Hole, MA (Mar. Sci. Int.), Ocean Margin Drilling Program, Regional Atlas Series, Sheet 14.

Carson, B., and Berglund, P. L., 1987. Sediment deformation and dewatering under horizontal compression: Experimental results. In Moore, J. C. (Ed.), Structural Fabrics in Deep Sea Drilling Project Cores from Forearcs. Geol. Soc. Am. Mem., 166:135-150.

Choquette, P. W., and Pray, L. C., 1970. Geologic nomenclature and classification of porosity in sedimentary carbonates. AAPG Bull., 54:207-250.

Claypool, G. E., and Kaplan, I. R., 1974. The origin and distribution of methane in marine sediments. In Kaplan, I. R. (Ed.), Natural Gases in Marine Sediments: New York (Plenum Press), 99-139.

Cloos, M., 1984. Landward-dipping reflectors in accretionary wedges: Active dewatering conduits? Geology, 12:519-522. 
COSOD II, 1988. Rept. 2nd Conf. Scientific Ocean Drilling, JOIDES and European Sci. Found., Strasbourg, 6-8 July 1987.

Folk, R. L., 1965. Some aspects of recrystallization in ancient limestones. In Pray, L. C., and Murray, R. C. (Eds.), Dolomitization and Limestone Diagenesis, A Symposium. Soc. Econ. Paleontol. Mineral. Spec. Publ., 13:14-48.

Folk, R. L., and Land, L. S., 1975. Mg/Ca ratio and salinity: Two controls over crystallization of dolomite. AAPG Bull., 59:60-68.

Fritz P., and Smith, D.C.W., 1970. The isotope composition of secondary dolomites. Geochim. Cosmochim. Acta, 34:1161-1173.

Gensmer, R. P., and Weiss, M. P., 1980. Accuracy of calcite/dolomite ratios by X-ray diffraction and comparison with results from staining techniques. J. Sediment. Petrol., 50:626-629.

Gieskes, J. M., and Lawrence, J. R., 1981. Alteration of volcanic matter in deep sea sediments: Evidence from the chemical composition of interstitial waters from deep sea drilling cores. Geochim. Cosmochim. Acta, 45:1687-1703.

Gieskes, J., Blanc, G., Vrolijk, P., Moore, J. C., Mascle, A., Taylor, E., Andreiff, P., Alvarez, F., Barnes, R., Beck, C., Behrmann, J., Brown, K., Clark, M., Dolan, J., Fisher, A., Hounslow, M., McLellan, P., Moran, K., Ogawa, Y., Sakai, T., Schoonmaker, J., Wilkens, R., Williams, C., in press. Hydrogeochemistry in the Barbados Accretionary Complex: ODP Leg 110. Tectonophysics.

Given, R. K., and Wilkinson, B. H., 1985. Kinetic control of morphology, composition, and mineralogy of abiotic sedimentary carbonates. J. Sediment. Petrol., 55:0109-0119.

Han, M. W., and Suess, E., in press. Subduction-induced pore fluid venting and the formation of authigenic carbonates along the Oregon/ Washington continental margin: implications for the global $\mathrm{Ca}$ cycle. Palaeogeogr., Palaeoclimatol., Palaeoecol., Spec. Issue.

Hussong, D. M., Edwards, P. P., Johnson, S. H., Campbell, J. F., and Sutton, G. H., 1976. Crustal structure of the Peru-Chile Trench: $8^{\circ} \mathrm{S}-12^{\circ} \mathrm{S}$ latitude. In Sutton, G. H., Manghnani, M. H., and Moberly, R. (Eds.), The Geophysics of the Pacific Ocean Basin and Margin. Am. Geophys. Union Mono., 19:71-85.

Hussong, D. M., Reed, T. B., IV, and Bartlett, W. A., 1988. SeaMARC II sonar imagery and bathymetry of the Nazca Plate and Peru Forearc, ODP Leg 112. In Suess, E., von Huene, R., et al., Proc. ODP, Init. Repts., 112: College Station, TX (Ocean Drilling Program), 125-130.

Irwin, H., 1980. Early diagenetic carbonate precipitation and pore fluid migration in the Kimmeridge Clay of Dorset, England. Sedimentology, 27:577-591.

Irwin, H., Curtis, C. D., and Coleman, M., 1977. Isotopic evidence for source of diagenetic carbonates formed during burial of organic-rich sediments. Nature, 269:209-213.

Kelts, K., and McKenzie, J. A., 1982. Diagenetic dolomite formation in Quaternary anoxic diatomaceous muds of Deep Sea Drilling Project, Leg 64, Gulf of California. In Curray, J. R., Moore, D. G., et al., Init. Repts DSDP, 64: Washington (U.S. Govt. Printing Office), 553-570.

Kennicutt, M. C., Brooks, J. M. Bidigar, R. R., Fay, R. R., Wade, T. L., and McDonald, T. J., 1985. Vent-type taxa in a hydrocarbon seep region on the Louisiana slope. Nature, 317:351-353.

Kulm, L. D., Schrader, H. J., Resig, J. M., Thornburg, T., Masias, A., and Johnson, L., 1981. Late Cenozoic carbonates on the Peru continental margin: lithostratigraphy, biostratigraphy, and tectonic history. In Kulm, L. D., Dymond, J., Dasch, E. J., and Hussong, D. M. (Eds.), Nazca Plate: Crustal Formation and Andean Convergence. Geol. Soc. Am. Mem., 154:469-507.

Kulm, L. D., Suess, E., and Thornburg, T. M., 1984. Dolomites in organic-rich muds of the Peru forearc basins: Analogue to the Monterey Formation. In Garrison, R. E., Kastner, M., and Zenger, D. H., (Eds.), Dolomites of the Monterey Formation and Other Organic-Rich Units. Pacific Sect., Soc. Econ. Paleontol. Mineral., 41:29-47.

Kulm, L. D., Suess, E., Moore, J. C., Carson, B., Lewis, B. T., Ritger, S. D., Kadko, D.C., Thornburg, T. M., Embley, R. W., Rugh, W. D., Massoth, G. J., Langseth, M. G., Cochrane, G. R. and Scammon, R. L., 1986. Oregon subduction zone: venting, fauna and carbonates. Science, 231:561-566.

Kulm, L. D., Thornburg, T. M., Suess, E., Resig, J., and Fryer, P., 1988. Clastic, diagenetic, and metamorphic lithologies of a subsiding continental block: Central Peru Forearc. In Suess, E., von
Huene, R., et al., Proc. ODP, Init. Repts., 112: College Station, TX (Ocean Drilling Program), 91-107.

Lawrence, J. R., Gieskes, J., and Broecker, W. S., 1975. Oxygen isotope and cation composition of DSDP pore waters and the alteration of layer II basalts. Earth Planet. Sci. Lett., 27:1-10.

Longman, M. W., 1980. Carbonate diagenetic textures from nearsurface diagenetic environments. AAPG Bull., 64:461-487.

McKee, E. H., and Noble, D. C., 1982. Miocene volcanism and deformation in the Western Cordillera and high plateaus of southcentral Peru. Geol. Soc. Am. Bull., 93:657-662.

Moore, J. C., Mascle, A., Taylor, E., Andreiff, P., Alvarez, F., Barnes, R., Beck, C., Behrmann, J., Blanc, G., Brown, K., Clark, M., Dolan, J., Fisher, A., Gieskes, J., Hounslow, M., McClellan, P., Moran, K., Ogawa, Y., Sakai, T., Schoonmaker, J., Vrolijk, P., Wilkens, R., Williams, C., 1987. Expulsion of fluids from depth along a subduction-zone dècollement horizon. Nature, 326:785788.

Moore, G. F., and Taylor, B., 1988. Structure of the Peru Forearc from multichannel seismic-reflection data. In Suess, E., von Huene, R., et al., Proc. ODP, Init. Repts., 112: College Station, TX (Ocean Drilling Program), 71-76.

Noble, D. C., McKee, E. H., and Megard, E., 1979. Early Tertiary "Incaic" tectonism, uplift, and volcanic activity, Andes of central peru. Geol. Soc. Am. Bull., 90:903-907.

Pardo-Casas, F., and Molnar, P., 1987. Relative motion of the Nazca (Farallon) and South American plates since late Cretaceous time. Tectonics, 6:233-248.

Pisciotto, K. A., and Mahoney, J. J., 1981. Isotopic survey of diagenetic carbonates, Deep Sea Drilling Project, Leg 63. In Yeats, R. S., Haq, B. U., et al., Init. Repts DSDP, 63: Washington (U.S. Govt. Printing Office), 595-610.

Redwine, L., 1981. Hypothesis combining dilation, natural hydraulic fracturing and dolomitization to explain petroleum reservoirs in Monterey shale, Santa Maria area, California. In Garrison, R. E., Douglas, R. G., Pisciotto, K. E., Isaacs, C. M., and Ingle, J. C. (Eds.), The Monterey Formation and Related Siliceous Rocks of California. Soc. Econ. Paleontol. Mineral., Pacific Sect. Spec. Publ., 221-248.

Ritger, S., Carson, B., Suess, E., 1987. Methane-derived authigenic carbonates formed by subduction-induced pore water expulsion along the Oregon/Washington Margin. Geol. Soc. Am. Bull., 98:147-156.

Roehl, P. O., 1981. Dilation brecciation-A proposed mechanism of fracturing, petroleum expulsion and dolomitization in the Monterey Formation, California. In Garrison, R. E., Douglas, R. G., Pisciotto, K. E., Isaacs, C. M., and Ingle, J. C. (Eds.), The Monterey Formation and Related Siliceous Rocks of California. Soc. Econ. Paleontol. Mineral., Pacific Section, Spec. Publ., 285-315.

Shi, Y., Wang, C.-Y., Hwang, W., and von Huene, R., 1989. Hydrogeological modeling of porous flow in the Oregon accretionary prism. Geology, 17:320-323.

Shipboard Scientific Party, 1988. Site 688. In Suess, E., von Huene, R., et al., 1988. Proc. ODP, Init. Repts., 112: College Station, TX (Ocean Drilling Program), 873-1004.

Suess, E., Carson, B., Ritger, S. D., Moore, J. C., Kulm, L. D., and Cochrane, G. R., 1985. Biological communities at vent sites along the subduction zone off Oregon. In Jones, M. L. (Ed.), The Hydrothermal Vents of the Eastern Pacific: An Overview. Bull. Biol. Soc., Washington, N6:475-484.

Suess, E., Kulm, L. D., and Killingley, J. S., 1987a. Coastal upwelling and a history of organic-rich mudstone deposition off Peru. In Brooks, J., and Fleet, A. J. (Eds.), Marine Petroleum Source Rocks. Geol. Soc. London Spec. Publ., 24:181-197.

Suess, E., von Huene, R., and Leg 112 Scientific Party, 1987b. Plate convergence and coastal upwelling: Geologic history of the Peru margin. Geotimes, May, 1987:10-12.

Suess, E., and Whiticar, M. J., in press. Methane-derived $\mathrm{CO}_{2}$ in pore fluids expelled from the Oregon subduction complex. Palaeogeogr., Palaeoclimatol., Palaeoecol. Spec. Issue.

Suess, E., von Huene, R., and Leg 112 Scientific Party, 1988. ODP Leg 112, Peru continental margin: Part 2. Sedimentary history and diagenesis in a coastal upwelling environment. Geology, 16:939943. 
Thornburg, T. M., 1985. Seismic stratigraphy of Peru forearc basins. In Hussong, D. M., Dang, S. P., Kulm, L. D., Couch, R. W., and Hilde, T. C. (Eds.), Atlas of the Ocean Margin Drilling Program, Peru Continental Margin, Region VI: Woods Hole, MA (JOI, Inc., Mar. Sci. Int.).

Thornburg, T. M., and Kulm, L. D., 1981. Sedimentary basins of the Peru continental margin: Structure, stratigraphy and Cenozoic tectonics from $6^{\circ} \mathrm{S}$ to $16^{\circ} \mathrm{S}$ latitude. In Kulm, L. D., et al. (Eds.), Nazca Plate: Crustal Formation and Andean Convergence. Geol. Soc. Am. Mem., 154:393-422.

Thornburg, T. M., Marocco, R., and Davila, D., 1985. Geological cross sections. In Hussong, D. M., Dang, S. P., Kulm, L. D., Couch, R. W., and Hilde, T. C. (Eds.), Atlas of the Ocean Margin Drilling Program, Peru Continental Margin, VI: Woods Hole, MA (JOI, Inc., Mar.Sci. Int.).

Travis, R. B., Gonzales, G., and Pardo, A., 1976. Hydrocarbon potential of coastal basins of Peru. In Halbouty, M. T., Maher, J. C., Lian, H. M., (Eds.), Circum-Pacific Energy and Mineral Resources. AAPG Mem., 331-338. von Huene, R., Suess, E., and Leg 112 Scientific Party, 1988. ODP Leg 112, Peru continental margin: Part 1, tectonic history. Geology, 116:934-938.

von Huene, R., and Miller J. 1988. Migrated multichannel seismicreflection records across the Peru continental margin. In Suess E., von Huene, R., et al., Proc. ODP, Init. Repts., 112: College Station, TX (Ocean Drilling Program), 109-124.

Vrolijk, P., 1987. Tectonically driven fluid flow in the Kodiak accretionary complex, Alaska. Geology, 15:466-469.

Vrolijk, P., Chambers, S. R., Gieskes, J. M., and O'Neil, J. R., 1990. Oxygen and hydrogen isotope ratios of interstitial waters from the northern Barbados accretionary prism, ODP Leg 110. In Moore, J. C., Mascle, A., et al., Proc. ODP, Sci. Results, 110: College Station, TX (Ocean Drilling Program).

Date of initial receipt: 3 November 1988

Date of acceptance: 3 August 1989

Ms 112B-139 